\title{
INTERNALISASI SEKTOR PERBANKAN DALAM MODEL DSGE
}

\author{
Harmanta \\ Nur M. Adhi Purwanto \\ Fajar Oktiyanto ${ }^{1}$
}

\begin{abstract}
We build DSGE model for small open economy with financial friction in the form of collateral constrain on banking sector, designed for Indonesian economy. The constructed model is capable to simulate the monetary policy (Bank Indonesia rate) and macroprudential policy (reserve requirement, capital adequacy ratio - CAR, and loan to value - LTV). By internalizing banking sector into the model, this model also enable us to simulate the impact of any shock originated from banking sector.
\end{abstract}

Keywords: monetary policy, DSGE with banking sector, macroprudential policy

JEL Classification: E32, E44, E52, E58

1 Harmanta (corresponding author; harmanta@bi.go.id), Nur M. Adhi Purwanto (adhipd@bi.go.id), and Fajar Oktiyanto (fajar_o@ bi.go.id) are researchers in Bank Indonesia. Authors thank to Dr. Iskandar Simorangkir and Prof. Dr. Ari Kuncoro for their great comments and to all participant of the seminar on November 27, 2012 at Bank Indonesia. Author also thank to Andre Raymond for his great assistance and his contribution on this research. 


\section{PENDAHULUAN}

Sejumlah krisis ekonomi dan keuangan yang terjadi dalam beberapa dekade terakhir menunjukkan bahwa ketidakstabilan makroekonomi lebih banyak bersumber dari sektor keuangan/perbankan yang sifatnya sangat prosiklikal. Agung (2010) menyatakan bahwa tingkat prosiklikalitas dari sektor keuangan di Indonesia tergolong cukup tinggi. Hal ini terlihat dari tumbuhnya kredit riil yang lebih cepat dari PDB pada periode ekspansi, dan penurunan yang jauh lebih besar dari penurunan PDB pada periode kontraksi. Tingginya prosiklikalitas sektor perbankan di Indonesia tersebut menuntut sinergi kebijakan moneter dan kebijakan makroprudensial untuk memitigasi fluktuasi ekonomi (business cycle) yang berlebihan.

Kebijakan moneter berpotensi mendukung stabilitas sistem keuangan melalui kemampuannya mempengaruhi kondisi keuangan dan perilaku di pasar keuangan, melalui transmisi neraca keuangan perusahaan dan bank serta perilaku pengambilan resiko. Demikian pula sebaliknya, kondisi dari sistem keuangan juga memiliki potensi untuk mempengaruhi stabilitas moneter. Untuk membantu Bank Indonesia dalam merumuskan kebijakan yang akan mempengaruhi stabilitas moneter maupun sistem keuangan diperlukan adanya model ekonomi yang memiliki kemampuan untuk mensimulasikan efek dari kebijakan moneter dan makroprudensial terhadap sektor keuangan/perbankan dan perekonomian secara keseluruhan.

Tujuan dari penelitian ini adalah untuk mengembangkan model DSGE yang dilengkapi dengan sektor perbankan untuk keperluan simulasi kebijakan moneter maupun makroprudensial. Manfaat yang didapatkan dari dilakukannya penelitian ini antara lain adalah sebagai salah satu alat bantu dalam melakukan formulasi kebijakan yang akan ditetapkan oleh Bank Indonesia. Selain itu, pengembangan model ini juga merupakan salah satu langkah dalam competence building dalam mengembangkan model DSGE dengan fitur simulasi kebijakan moneter dan makroprudensial yang beragam untuk kebutuhan pengembangan core model FPAS di masa yang akan datang (sesuai best practice dari advanced countries yang saat ini telah mengadopsi core model berbasis DSGE).

Bagian kedua dari paper ini mengulas teori yang terkait dengan model, terutama pondasi mikro (microeconomic underpinning) para agen ekonomi yang ada dalam model. Bagian ketiga mengulas metodologi dalam menguji validitas dan konsistensi model, termasuk kemampuan model dalam melakukan simulasi. Bagian keempat dari paper ini menyajikan hasil dan analisis, sementara kesimpulan dan saran disajikan pada bagian terakhir.

\section{TEORI}

Salah satu komponen yang jarang ditemukan dalam model yang digunakan oleh bank sentral, terutama untuk periode sebelum krisis global 2007/8 adalah sektor keuangan yang dilengkapi dengan financial frictions. Hal ini sangatlah disayangkan karena mekanisme 
transmisi dari kebijakan makroekonomi sangatlah bergantung pada karakteristik dari sektor keuangan. Seperti disebutkan oleh Roger dan Vleck (2011), penambahan jalur kredit dan adanya intermediasi keuangan di dalam model makroekonomi yang digunakan oleh bank sentral akan sangat membantu menjelaskan dinamika dari siklus bisnis yang dipengaruhi oleh prosiklikalitas dari sektor keuangan. Selain itu, mereka juga menyebutkan pentingnya memodelkan neraca dari rumah tangga serta pengaruh dari durable assets seperti rumah (housing) terhadap transmisi dari kebijakan makroekonomi.

\subsection{Permodelan Financial Friction dalam DSGE Model}

Berdasarkan literatur yang berkembang sampai dengan saat ini, terdapat 2 pendekatan utama yang dapat digunakan untuk memasukkan financial frictions ke dalam model DSGE: pendekatan financial accelerator dan collateral constraints. Masing-masing pendekatan ini memiliki kelemahan dan kekuatan yang masih terus diperdebatkan oleh para ahli ekonomi, baik di kalangan akademis maupun bank sentral

Asumsi dasar dari pendekatan financial accelerator adalah adanya information asymmetry antara peminjam dan yang meminjamkan sehingga menghasilkan external finance premium, yang menggambarkan perbedaan antara biaya apabila melakukan peminjaman dibandingkan dengan apabila menggunakan dana sendiri. External borrowing premium ditentukan oleh besarnya net worth dari peminjam dan akan menentukan besarnya pinjaman yang dapat diterima. Net worth didefinisikan sebagai besarnya aset yang dimiliki oleh peminjam dikurangi dengan kewajiban hutang yang dimilikinya. Di saat ekonomi sedang dalam kondisi lebih baik, peminjam memiliki net-worth yang juga lebih baik, meningkatkan kelayakannya untuk meminjam (credit worthiness) dan menurunkan external finance premium. Sebaliknya, ketika ekonomi sedang buruk, net-worth yang rendah akan menurunkan credit worthiness dan meningkatkan biaya untuk meminjam. Dinamika dari external finance premium yang counter-cylical adalah mekanisme yang memperbesar (amplify) respon dari PDB dan investasi terhadap adanya shock. Sebagai contoh, respon awal dari PDB terhadap shock dari teknologi akan diperbesar dengan meningkatnya harga aset yang juga timbul akibat shock tersebut. Tingginya harga aset akan meningkatkan net worth dari peminjam yang akan menyebabkan turunnya external finance premium yang kemudian akan meningkatkan investasi. Pendekatan financial accelerator dapat membantu menjelaskan besarnya perubahan dari investasi dan respon output yang berbentuk hump-shaped terhadap perubahan suku bunga yang sifatnya moderat.

Serupa dengan pendekatan financial accelerator, mekanisme dasar dari pendekatan collateral constraint adalah pergerakan dari harga aset yang berinteraksi dengan ketidaksempurnaan yang terdapat dalam credit market membuat suatu proses yang memperbesar respon dari shock. Namun, berbeda dengan pendekatan financial accelerator, net worth dari peminjam secara langsung akan mempengaruhi besarnya pinjaman yang dapat diterima dan tidak melalui pengaruhnya terhadap external finance premium. Dalam rangka 
menyediakan insentif bagi peminjam untuk mengembalikan pinjamannya, pemberi pinjaman mengharuskan adanya kolateral ketika memberikan pinjaman. Aset yang bersifat durable seperti tanah, rumah maupun barang modal biasanya yang digunakan sebagai kolateral.

Pendekatan financial accelerator maupun collateral constraint pada awalnya mengasumsikan bahwa penerima pinjaman dapat langsung mendapatkan dana dari pemberi pinjaman tanpa adanya intermediasi keuangan yang dilakukan bank. Memperkenalkan sektor perbankan ke dalam model DSGE akan memberikan tambahan metode dalam memodelkan financial friction terutama yang terkait dengan biaya dari intermediasi.

Instrumen dari kebijakan makroprudensial ditujukan untuk mencegah ataupun menghambat efek prosiklikalitas dari sistem keuangan. Instrumen seperti batasan loan to value ratio, counter-cyclical capital requirement dan time-varying reserve requirement bekerja melalui neraca dari sektor perbankan ataupun neraca dari peminjam. Hal ini membuat keberadaan financial friction dan neraca sektor perbankan yang dimodelkan secara eksplisit adalah salah satu syarat yang harus dipenuhi untuk dapat mensimulasikan mekanisme transmisi dari instrumen kebijakan makroprudensial.

Gerali et al (2010) mengembangkan model DSGE yang dilengkapi dengan sektor perbankan yang kemudian banyak dijadikan dasar pengembangan model untuk kebutuhan simulasi kebijakan makroprudensial di berbagai bank sentral. Model yang dikembangkan adalah model DSGE untuk ekonomi tertutup dengan friksi pada pasar kredit berupa borrowing constraint dan sektor perbankan yang beroperasi pada kondisi monopolistic competitive. Didalam model terdapat terdapat agen yang berfungsi sebagai pemberi pinjaman (patient households) dan peminjam (impatient households dan pengusaha). Kedua agen peminjam harus menghadapi borrowing constraint berupa collateral constraint ala Lacoviello (2005) yang dikaitkan dengan jumlah aset yang dimilikinya (aset perumahan untuk impatient households dan barang modal untuk pengusaha). Neraca bank yang dimodelkan terdiri dari deposito dan modal di sisi liabilities, dan pinjaman yang disalurkan ke agen peminjam di sisi aset. Bank melakukan akumulasi modal melalui retained earnings (laba ditahan) dan harus memenuhi persyaratan Capital Adequacy Ratio (CAR) yang ditetapkan oleh bank sentral. Diasumsikan bahwa bank memiliki market power pada pasar penghimpunan dan penyaluran dana dan bank menetapkan tingkat suku bunga yang berbeda untuk pinjaman yang diberikan pada impatient households dan pengusaha. Diasumsikan juga bahwa terdapat "stickiness" dari respon suku bunga retail perbankan terhadap dinamika dari suku bunga kebijakan. 


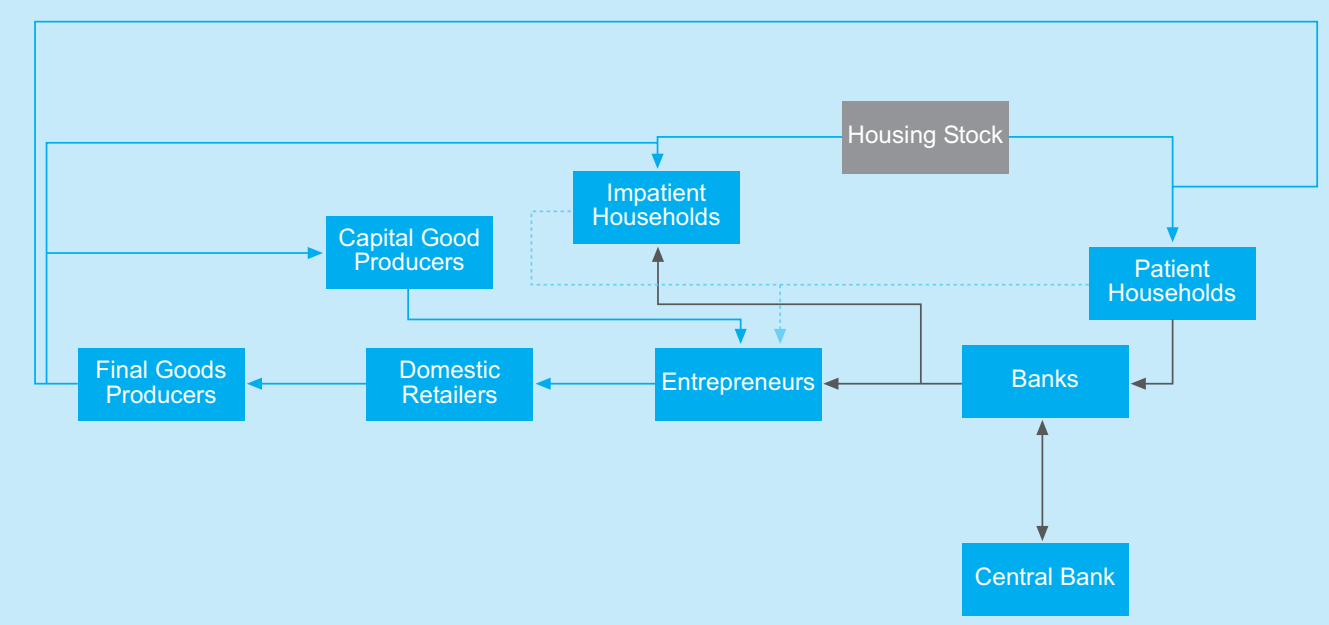

Diagram 1. Skema Model Gerali et al (2010)

Model Gerali et al (2010) diestimasi secara Bayesian dengan menggunakan data dari Euro area. Model tersebut telah diaplikasikan untuk mempelajari peran dari keberadaan financial friction dan intermediasi keuangan oleh bank dalam menentukan dinamika dari siklus bisnis, khususnya terkait dengan bagaimana transmisi dari kebijakan moneter menuju sektor riil dipengaruhi oleh kedua hal tersebut. Selain itu Angelini et al (2010) juga menggunakan model ini untuk mempelajari prosiklikalitas ekstra yang disebabkan oleh Basel II jika dibandingkan dengan Basel I. Di tahun 2011, Angelini et al kembali mengaplikasikan model Gerali untuk mempelajari interaksi antara kebijakan moneter dengan kebijakan makroprudensial.

\subsection{Karakteristik Sektor Perbankan Indonesia}

Salah satu asumsi yang diterapkan dalam permodelan sektor perbankan dalam model DSGE oleh beberapa bank sentral adalah adanya market power dari bank dalam pasar penghimpunan maupun penyaluran dana sehingga bank memiliki kekuatan dalam menentukan tingkat suku bunga DPK maupun suku bunga kredit. Beberapa penelitian empiris di Indonesia mendukung asumsi ini. Salah satunya adalah Purwanto (2009) yang menyimpulkan bahwa dinamika spread suku bunga perbankan (didefinisikan sebagai perbedaan antara suku bunga penyaluran dana dikurangi dengan suku bunga penghimpunan dana) sebagian besar dipengaruhi oleh dinamika dari tingkat konsentrasi industri perbankan di Indonesia. Dalam penelitian tersebut, digunakan Herfindahl-Hirschman Index sebagai ukuran dari tingkat konsentrasi Industri perbankan. Berdasarkan estimasi model empiris menggunakan data bulanan individual bank (panel) mulai 
Januari 2002 sampai dengan April 2009, disimpulkan bahwa penurunan spread suku bunga selama periode estimasi disebabkan oleh peningkatan kompetisi di sektor perbankan karena terjadinya peningkatan market share dari sebagian besar bank yang diikuti dengan penurunan market share dari bank dengan aset besar. Hal ini sejalan dengan penelitian yang menggunakan pendekatan Structure-Conduct-Performance yang menghubungkan konsentrasi pasar dengan kekuatan pasar (market power) dan perilaku penentuan suku bunga (Berger et al ,2004).

Selain itu, dalam model DSGE yang dikembangkan berbagai bank sentral juga diasumsikan bahwa terdapat "stickiness" dalam suku bunga retail perbankan jika dikaitkan dengan dinamika dari suku bunga kebijakan. Dari sudut pandang teoritis, bank dapat memandang bahwa adalah optimal untuk tidak terlalu sering mengubah suku bunga apabila permintaan konsumen bersifat inelastis dalam jangka pendek karena tingginya switching cost (Calem et al., 2006) atau karena adanya suatu fixed cost (menu cost) dalam melakukan perubahan tingkat suku bunga (Berger dan Hannan, 1991). Alasan teoritis lain yang juga dikemukakan oleh ahli ekonomi adalah adanya kepentingan bank untuk menjaga hubungan dengan konsumen sehingga melakukan interest rate smoothing untuk melindungi konsumen dari fluktuasi suku bunga pasar (kebijakan). Hal ini memungkinkan bank untuk menetapkan suku bunga yang tinggi di saat suku bunga kebijakan sedang rendah (Berger dan Udell, 1992).

Secara sederhana respon jangka pendek yang rigid dari suku bunga retail perbankan terhadap dinamika suku bunga kebijakan dapat dilihat pada hasil impulse response pada Grafik 1. Impulse response tersebut berasal dari bivariate VAR system² yang terdiri dari variabel : (1) BI rate dengan suku bunga kredit konsumsi; (2) BI rate dengan suku bunga kredit untuk perusahaan (rata-rata tertimbang antara suku bunga kredit investasi dengan kredit modal kerja); dan (3) BI rate dengan suku bunga DPK (rata-rata tertimbang untuk semua kategori DPK). Dapat dilihat dari Grafik 1 bahwa respon jangka pendek dari suku bunga retail bank terhadap perubahan dari BI rate cukup terbatas, terutama untuk suku bunga kredit konsumsi. Suku bunga deposito dan suku bunga kredit untuk perusahaan memiliki respon yang kurang lebih sama. Walaupun nilainya tidak sekecil respon dari suku bunga konsumsi namun tetap menunjukkan tingkat stickiness yang juga cukup tinggi.

2 Masing-masing VAR system juga terdiri dari variabel eksogen, yaitu besarnya reserve ratio untuk VAR dari suku bunga deposito; dan besarnya modal, bobot asset beresiko (ATMR dibagi total kredit), dan besarnya pinjaman yang disalurkan untuk VAR suku bunga pinjaman. 
Response to Cholesky One S.D. Innovations \pm 2 S.E.

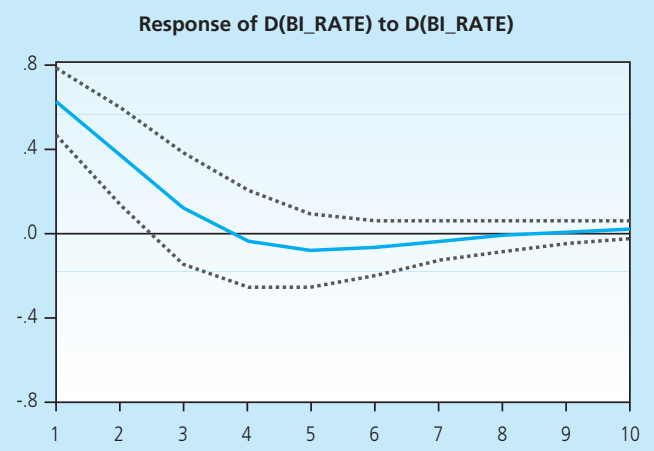

Response of D(R_PINJAMAN_CONS) to D(BI_RATE)

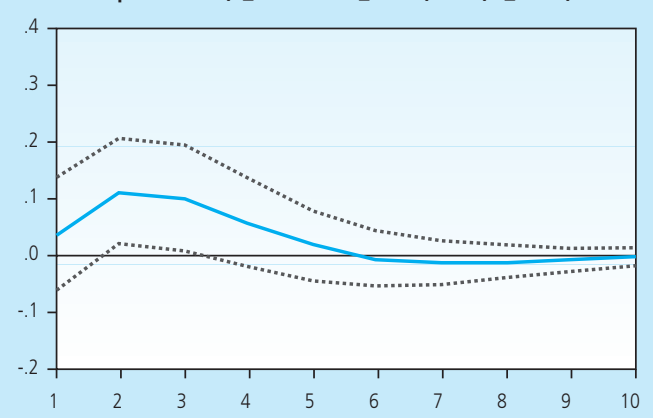

Response to Cholesky One S.D. Innovations \pm 2 S.E.

Response of D(BI_RATE) to D(BI_RATE)

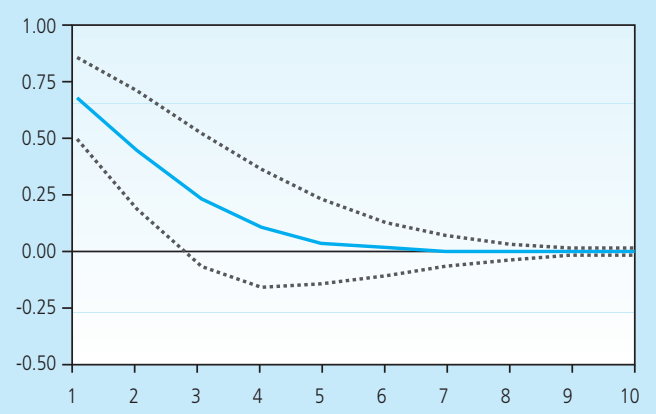

Response of D(R_DPK) to D(BI_RATE)

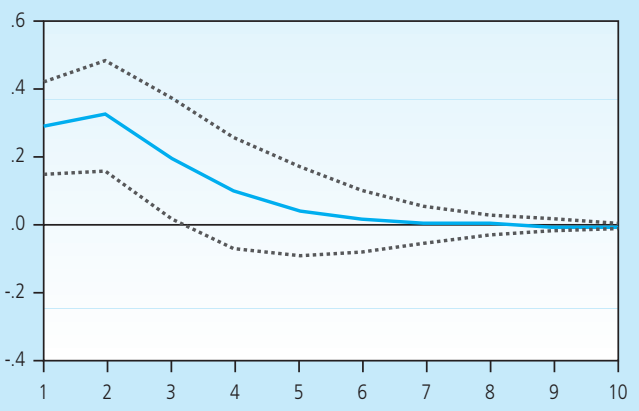

Response to Cholesky One S.D. Innovations \pm 2 S.E.

Response of $D\left(B I \_R A T E\right)$ to $D\left(B I \_R A T E\right)$

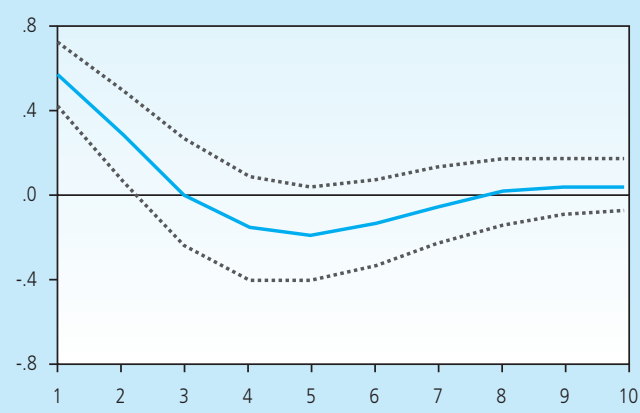

Response of D(R_PINJAMAN_ENT) to D(BI_RATE)

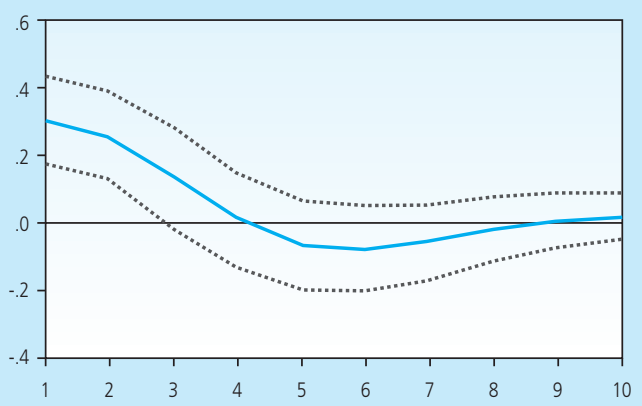

Grafik 1. Impulse Response dari Bivariate VAR System yang terdiri dari suku bunga kebijakan dan suku bunga retail kredit bank (agregat) 


\subsection{Struktur Model}

Model yang dikembangkan untuk penelitian ini didasari oleh model Gerali et al (2010) yang telah memasukkan sektor perbankan dalam New Keynesian DSGE Model ala Christiano et al (2005). Modifikasi utama dilakukan dengan menerapkan asumsi small open economy dan menambahkan agen Pemerintah untuk memperkaya kemampuan melakukan simulasi kebijakan makroekonomi. Fitur standar model DSGE yang meliputi adanya habit persistence dalam melakukan konsumsi, adanya adjustment cost terkait perubahan investasi, permodelan sticky prices dan sticky wages telah ada dalam model yang dikembangkan ini. Skema Model secara lengkap dapat dilihat pada Diagram 2.

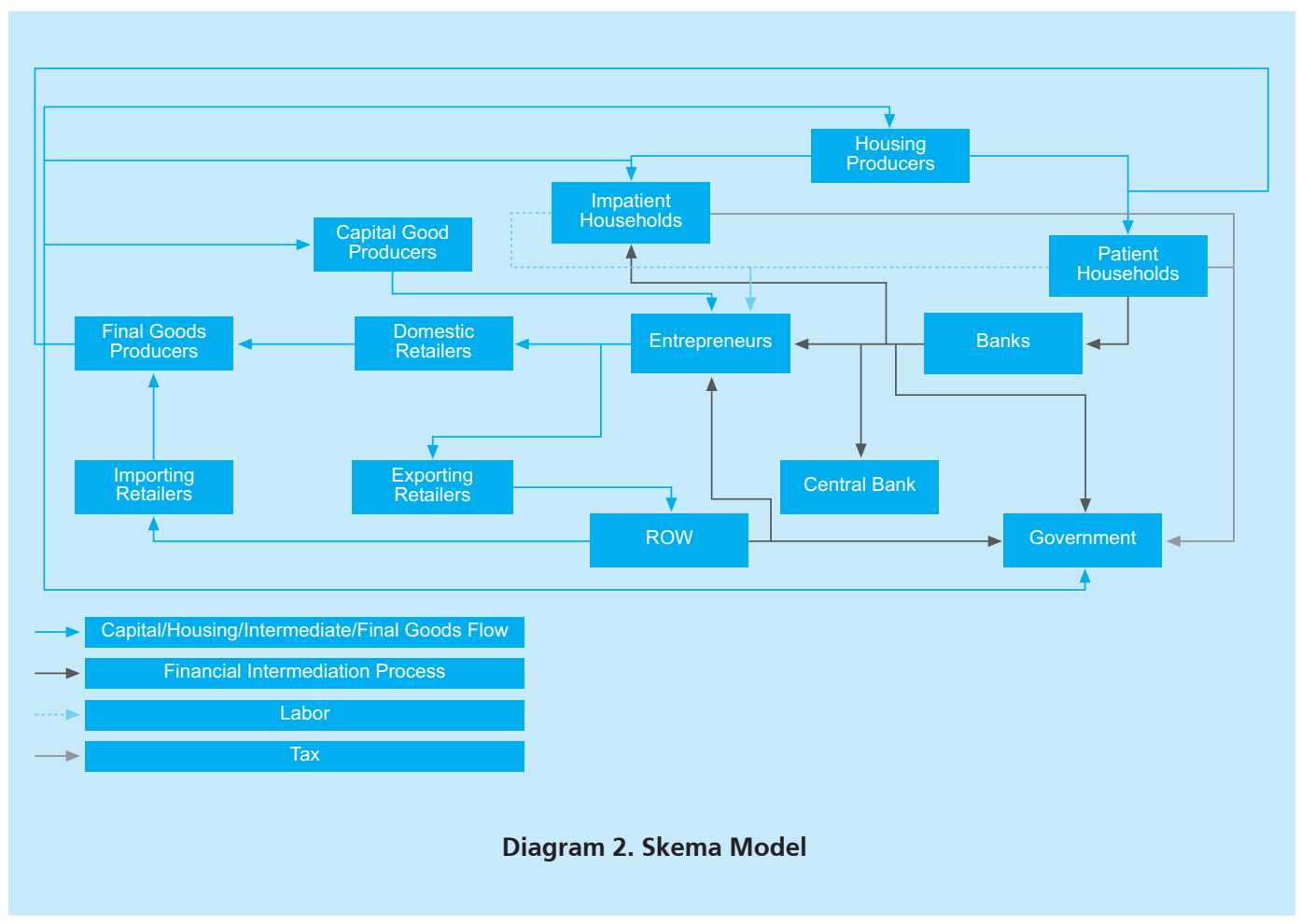

Didalam model terdapat dua kelompok rumah tangga (household), Patient dan Impatient Households serta Pengusaha (Entrepreneur). Perbedaan diantara ketiga agen ini adalah pada discount factor, dimana Patient Households memiliki nilai discount factor yang lebih tinggi daripada Impatient Households dan Entrepreneur ${ }^{3}$. Households melakukan kegiatan konsumsi,

3 Hal ini untuk memastikan bahwa dalam ekuilibrium collateral constraint yang ditetapkan bersifat binding dan patient households berlaku sebagai savers sedangkan impatient households dan entrepreneurs berlaku sebagai borrowers. Untuk keterangan lebih lanjut lihat lacovielo (2005) dan Liu et al (2010) 
menyediakan tenaga kerja, membayar pajak kepada pemerintah dan mengakumulasi aset perumahan, sementara pengusaha menghasilkan homogeneous intermediate goods dengan menggunakan barang modal (capital) yang dibeli dari capital goods producers dan pekerja yang berasal dari households. Homogeneous intermediate goods yang diproduksi oleh entrepreneur kemudian dijual kepada domestic retailer (untuk pasar domestik) dan exporting retailer (untuk pasar luar negeri) yang akan mengubahnya menjadi differentiated goods. Final goods producers akan bertindak sebagai aggregator yang akan menggabungkan intermediate differentiated goods yang berasal dari pasar domestik dengan yang berasal dari luar negeri (yang dibeli dari importing retailers).

Didalam model, terdapat juga capital goods producers dan housing producers yang menggunakan barang yang dihasilkan oleh final goods producers untuk memproduksi barang modal (capital) dan perumahan (housing) dengan teknologi yang harus menghadapi investment adjustment cost. Adanya adjustment cost ini memungkinkan harga untuk barang modal dan perumahan berbeda dengan harga barang konsumsi.

Terdapat 2 jenis instrumen keuangan yang disediakan oleh Bank untuk agen ekonomi dalam model: tabungan (deposito) dan pinjaman/kredit. Agen ekonomi harus menghadapi borrowing constraint apabila akan meminjam uang dari bank. Borrowing constraints ini terkait dengan nilai kolateral yang dimilikinya, yaitu stok perumahan untuk households dan nilai dari barang modal untuk entrepreneur. Adanya perbedaan dalam discount factor para agen ekonomi memungkinkan adanya aliran keuangan di ekuilibrium dimana patient households sebagai pemberi pinjaman (memiliki deposito), sedangkan impatient households dan entrepreneurs meminjam kepada bank.

Sektor perbankan beroperasi didalam kondisi monopolistic competitive dimana bank menentukan tingkat suku bunga deposito maupun pinjaman untuk memaksimalkan keuntungan yang didapatkannya. Jumlah pinjaman yang disalurkan oleh bank dapat dibiayai oleh deposito yang dihimpun serta dari modal yang dimiliki. Modifikasi kami lakukan pada model Gerali et al (2010) dengan menambahkan risk free asset sebagai bagian dari asset yang dimiliki bank. Risk free asset ini dapat berupa SBI (Sertifikat Bank Indonesia) maupun SBN (Surat Berharga Negara). Selain meminjam melalui bank, pengusaha dan pemerintah juga memiliki akses terhadap pinjaman yang berasal dari luar negeri.

Dalam model ini, kami melakukan modifikasi terhadap model awal yang dikembangkan Gerali et al (2010) dalam hal proses intermediasi keuangan yaitu beberapa agen dalam model ini juga memiliki akses terhadap sumber pembiayaan yang berasal dari luar negeri. Untuk kebutuhan penyederhanaan model, hanya entrepreneur dan pemerintah yang memiliki akses ke pembiayaan luar negeri.

Sesuai dengan pendekatan model Gerali, kami juga mengasumsikan bahwa terdapat market power dari bank dalam pasar penghimpunan maupun penyaluran dana sehingga bank memiliki kekuatan dalam menentukan tingkat suku bunga deposito maupun suku bunga kredit. 
Selain itu, juga diasumsikan bahwa terdapat "stickiness" dalam suku bunga retail perbankan jika dikaitkan dengan dinamika dari suku bunga kebijakan. Neraca bank yang terdapat dalam model juga sedikit lebih detail dari model Gerali dengan penambahan risk free asset dan reserve sebagai bagian dari aset yang dimiliki oleh bank. Ini sesuai dengan kondisi neraca (agregat) perbankan Indonesia yang masih menunjukkan ekses likuiditas yang cukup besar dalam bentuk SBI dan SBN. Hal ini adalah penambahan yang cukup penting mengingat keberadaan ekses likuiditas ini dapat mempengaruhi transmisi dari kebijakan moneter maupun kebijakan makroprudensial.

\begin{tabular}{l|l}
\multicolumn{2}{c}{\begin{tabular}{c}
\multicolumn{2}{c}{ Tabel 1 } \\
Neraca Bank
\end{tabular}} \\
\multicolumn{1}{c|}{ Assets } & \multicolumn{1}{c}{ Liabilities } \\
\hline Total Loan & Deposit \\
\hline Risk Free Asset (SBI and SBN) & Capital \\
\hline Reserve & \\
\hline
\end{tabular}

Setiap bank dalam model terdiri dari 3 unit, yaitu dua buah cabang 'retail' dan satu 'wholesale' unit. Cabang retail yang pertama bertanggung jawab untuk memberikan pinjaman yang berbeda untuk impatient households dan kepada entrepreneurs, sedangkan cabang retail yang kedua bertanggung jawab untuk menghimpun deposito dari patient households.

Setiap wholesale unit beroperasi dalam pasar kompetisi sempurna dan berfungsi untuk mengelola neraca keseluruhan bank:

$$
R F_{t}+B_{t}=\left(1-\Gamma_{\mathrm{t}}\right) D_{t}+K_{t}^{b}
$$

Dimana $R F_{t}$ adalah risk free asset, $B_{t}$ adalah total pinjaman yang disalurkan oleh bank, $D_{t}$ adalah total deposito yang dihimpun, $\Gamma_{t}$ adalah reserve ratio yang ditentukan bank dan dipengaruhi oleh reserve ratio requirement yang ditentukan oleh bank sentral, dan $K_{t}^{b}$ adalah modal bank. 


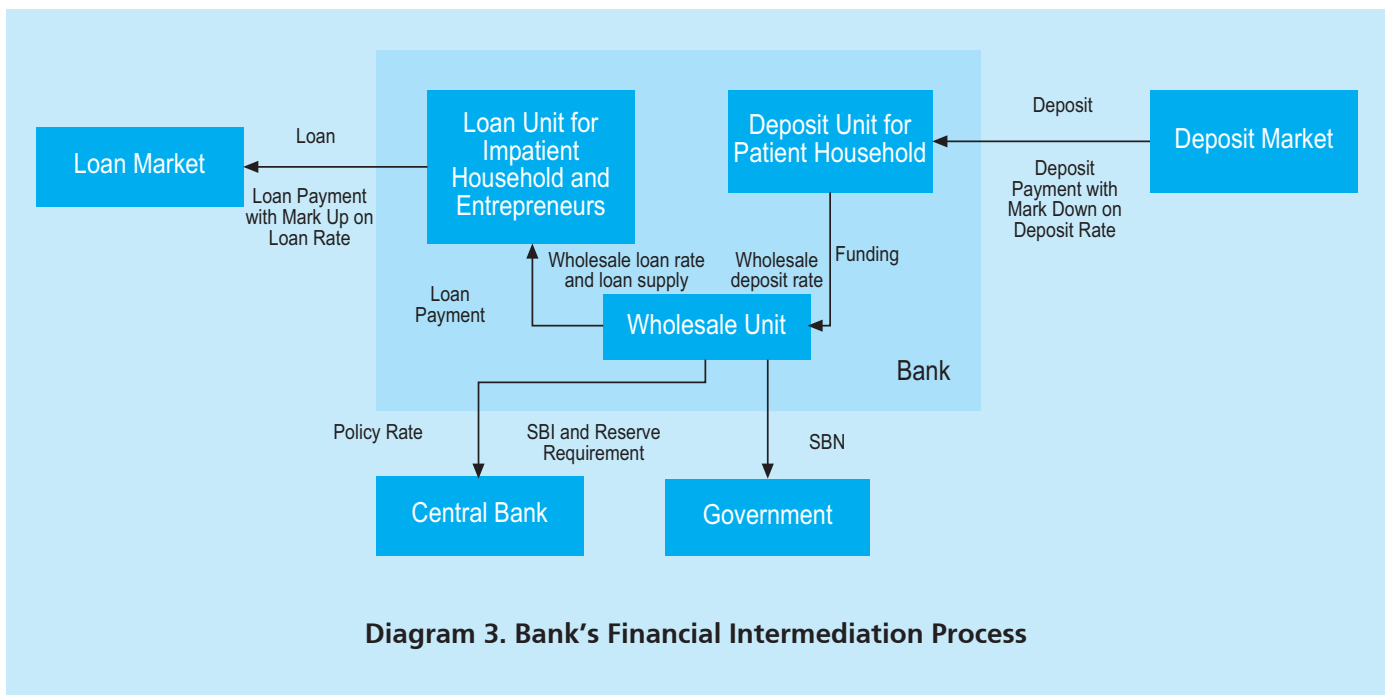

Diasumsikan bahwa bank tidak memiliki akses terhadap pembiayaan modal dari luar sehingga satu-satunya cara untuk meningkatkan modal yang dimiliki adalah melalui retained earning:

$$
K_{t}^{b}=\left(1-\delta^{b}\right) K_{t-1}^{b}+w^{b} j_{t-1}^{b}
$$

Dimana $J_{t}^{b}$ merupakan profit keseluruhan yang dihasilkan oleh ketiga unit bank, (1 $\left.w^{b}\right)$ menunjukkan porsi pembagian dividen bank; dan $\delta^{b}$ menunjukkan sumber daya yang digunakan dalam mengatur modal bank. Aturan mengenai dividen diasumsikan eksogen dan tetap, sehingga modal bank bukan merupakan variabel pilihan untuk bank. Secara lengkap, utility function dari wholesale unit adalah:

$$
\begin{gathered}
\operatorname{Max}_{\left\{\text {Ris }_{\text {freet }}, B t, D t\right\}} \\
E_{0} \Sigma_{s=0}^{\infty}\left(\beta_{P}\right) s \frac{\lambda_{t+s}^{P}}{\lambda_{t}^{P}}\left[\begin{array}{c}
\Gamma_{\mathrm{t}+s} D_{t+s}-\Gamma_{\mathrm{t}+s+1} D_{t+s+1}+\left(1+r_{t+s}\right) R F_{t+s}-R F_{t+s+1} \\
+\left(1+R_{t+s}^{b}\right) B_{t+s}-B_{t+s+1}+D_{t+s+1}-\left(1+R_{t+s}^{d}\right) D_{t+s} \\
+\Delta K_{t+s+1}^{b}-\left(\kappa_{K b} / 2\right)\left(K_{t+s}^{b} \omega_{t+s}^{b} B_{t+s}-v_{b, t+s}\right)^{2} K_{t+s}^{b}
\end{array}\right] \\
\text { s.t. } R F_{t}+B_{t}=\left(1-\Gamma_{\mathrm{t}}\right) D_{t}+K_{t}^{b}
\end{gathered}
$$

Dimana $\frac{\lambda_{t+s}^{P}}{\lambda_{t}^{P}}$ merupakan stochastic discount factor, $R_{t}^{b}$ adalah suku bunga pinjaman wholesale, $R_{t}^{d}$ adalah suku bunga deposito wholesale, dan $r_{t}$ merupakan suku bunga kebijakan bank sentral. FOC dari fungsi tujuan dari wholesale unit menggambarkan persamaan yang menentukan tingkat suku bunga pinjaman dan deposito yang diberikan ke loan branch dan deposit branch: 


$$
\begin{aligned}
& \mathrm{R}_{\mathrm{t}}^{\mathrm{b}}-\mathrm{r}_{\mathrm{t}}=-\left(\omega_{\mathrm{t}}^{\mathrm{b}}\right) \kappa_{\mathrm{Kb}}\left(\frac{\mathrm{K}_{\mathrm{t}}^{\mathrm{b}}}{\omega_{\mathrm{t}}^{\mathrm{b}} \mathrm{B}_{\mathrm{t}}}-\mathrm{v}_{\mathrm{b}, \mathrm{t}}\right)\left(\frac{\mathrm{K}_{\mathrm{t}}^{\mathrm{b}}}{\omega_{\mathrm{t}}^{\mathrm{b}} \mathrm{B}_{\mathrm{t}}}\right)^{2} \\
& \mathrm{r}_{\mathrm{t}}\left(1-\Gamma_{\mathrm{t}}\right)=\mathrm{R}_{\mathrm{t}}^{\mathrm{d}}
\end{aligned}
$$

Pada kondisi $C A R=\frac{K_{t}^{b}}{\omega_{t}^{b} B_{t}}=v_{b, t}$ maka $R_{t}^{b}=r_{t}$. Sedangkan dalam kondisi $C A R>v_{b, t}$ , maka bank akan bereaksi menurunkan CAR dengan meningkatkan jumlah penyaluran pinjaman $B_{t}$ (dengan menurunkan $R_{t}^{b}$ ), sehingga besarnya CAR dapat mendekati besaran aturan minimumnya, $C A R \approx v_{b, t}$.

Dalam kondisi GWM $=\Gamma_{\mathrm{t}}=0$, maka $\frac{R_{t}^{d}}{r_{t}}=1$, sedangkan dalam kondisi GWM $>0$ maka bank akan mengalami peningkatan opportunity cost dalam penyaluran dana sehingga bank bereaksi untuk menurunkan cost dengan mengurangi jumlah deposito atau setara dengan menurunkan $R_{t}^{d}$.

Mengikuti modifikasi yang dilakukan oleh Angelini et al (2011), kami juga memasukkan variabel bobot dari aset beresiko $\omega_{t}^{b}$ untuk memungkinkan perhitungan CAR (Capital Adequacy Ratio) yang lebih realistis pada model. Variabel bobot ini akan dikalikan dengan total pinjaman untuk menghasilkan Aktiva Tertimbang Menurut Risiko (ATMR). Adanya penambahan variabel bobot ini juga memungkinkan masuknya default risk sebagai salah satu variabel yang menentukan dinamika dari CAR yang dimiliki bank. Nilai dari $\omega_{t}^{b}$ yang menentukan besarnya ATMR tergantung dari komposisi aset beresiko yang dimiliki bank dan besarnya default risk. Untuk menggambarkan hubungan tersebut, kami menambahkan persamaan ad hoc sebagai berikut:

$$
\omega_{t}^{b}=\rho^{\omega} \omega_{t-1}^{b}+\left(1-\rho^{\omega}\right) \alpha_{a} \frac{b_{t}^{E}}{b_{t}^{I}}+\left(1-\rho^{\omega}\right) \alpha_{b} n p l_{t}
$$

Untuk $n p l_{t}$ yang merupakan proxy dari default risk, kami asumsikan memiliki dinamika $\mathrm{AR}(1)$ dengan error yang iid (indipendent and identically distributed).

Selain itu kami juga menambahkan persamaan ad hoc untuk menjelaskan dinamika dari rasio reserve yang dipilih oleh bank. Sebelumnya kami tetapkan terlebih dahulu dinamika dari reserve requirement ratio $\left(\hat{\Gamma}_{t}^{r}\right)$ yang ditentukan bank sentral sebagai berikut (dalam bentuk log linearisasi):

$$
\hat{\Gamma}_{t}^{r}=\rho_{\Gamma} \hat{\Gamma}_{t-1}^{r}+\hat{e}_{\Gamma^{\mathrm{r}}, t}
$$


Reserve requirement ratio ini kemudian akan menentukan besarnya ekses reserve $\left(\hat{\varepsilon}_{t}^{\Gamma}\right)$ yang ditentukan oleh bank:

$$
\hat{\varepsilon}_{t}^{\Gamma}=\rho_{\varepsilon} \hat{\varepsilon}_{t-1}^{\Gamma}+\left(1-\rho_{\varepsilon}\right) \hat{\Gamma}_{t}^{r}+\hat{e}_{\Gamma, t}
$$

Dan dinamika dari reserve adalah:

$$
\hat{\Gamma}_{\mathrm{t}}=\lambda_{\Gamma} \hat{\Gamma}_{t}^{r}+\left(1-\lambda_{\Gamma}\right) \hat{\varepsilon}_{t}^{\Gamma}
$$

Dalam model ini, tingkat kekuatan pasar yang dimiliki oleh bank ditentukan oleh besarnya (nilai steady state) elastisitas dari permintaan deposito maupun pinjaman. Semakin rendah nilai absolut dari elastisitas semakin tinggi kekuatan monopoli yang dimiliki bank. Diasumsikan bahwa kredit (simpanan) yang disalurkan ke (dihimpun dari) rumah tangga dan pengusaha (entrepreneur) adalah berupa keranjang komposit CES (Constant Elasticity of Subtitution) dari sejumlah produk yang slightly differentiated yang ditawarkan oleh cabang dari bank-j dengan elasticities of substitution sebesar $\varepsilon_{\mathrm{t}}^{\mathrm{bH}}, \varepsilon_{\mathrm{t}}^{\mathrm{bE}}$ dan $\varepsilon_{\mathrm{t}}^{\mathrm{d}}$. Ketiga nilai elastisitas ini akan mempengaruhi mark-up (untuk kredit) dan mark-down (untuk simpanan/DPK) yang ditetapkan oleh bank dalam menentukan tingkat suku bunga. Atau dengan kata lain, nilai elastisitas ini menentukan spread antara suku bunga kebijakan dengan suku bunga kredit (dan suku bunga deposito). Diasumsikan bahwa ketiga nilai elastisitas ini bersifat stochastic dan perubahan yang terjadi pada ketiga nilai tersebut dapat diinterpretasikan sebagai perubahan yang terjadi pada spread suku bunga retail bank yang terjadi di luar pengaruh dari kebijakan moneter.

Persamaan permintaan kredit untuk pengusaha $\left(\mathrm{b}_{\mathrm{t}}^{\mathrm{E}}\right)$ dan impatient households $\left(\mathrm{b}_{\mathrm{t}}^{\mathrm{l}}\right)$ :

$$
\begin{aligned}
& b_{t}^{I}(j)=\left(\frac{r_{t}^{b H}(j)}{r_{t}^{b H}}\right)^{-\varepsilon_{t}^{b H}} b_{t}^{I} \\
& b_{t}^{E}(j)=\left(\frac{r_{t}^{b E}(j)}{r_{t}^{b E}}\right)^{-\varepsilon_{t}^{b E}} b_{t}^{E}
\end{aligned}
$$

Persamaan permintaan simpanan $\left(d_{t}\right)$ oleh patient household:

$$
d_{t}(j)=\left(\frac{r_{t}^{d}(j)}{r_{t}^{d}}\right)^{-\varepsilon_{t}^{d}} d_{t}
$$

Loan branch mendapatkan wholesale loans $B_{t}$ dari wholesale unit dengan suku bunga $R_{t}^{b}$, kemudian menyalurkan kepada households dan entrepreneur dengan menerapkan dua markup yang berbeda. Dalam rangka untuk menerapkan stickiness dan untuk mempelajari implikasi 
dari imperfect bank pass-through, diasumsikan bahwa masing-masing bank menghadapi quadratic adjustment cost apabila melakukan perubahan suku bunga pinjaman. Besarnya biaya tersebut ditentukan oleh parameter $K_{b E}$ dan $K_{b H}$. Utility function dari loan branch adalah sebagai berikut:

$$
\begin{aligned}
\max _{\left\{r_{t}^{b H}(j), r_{t}^{b E}(j)\right\}} E_{0} & \sum_{s=0}^{\infty}\left(\beta_{P}\right)^{s} \frac{\lambda_{t+s}^{P}}{\lambda_{t}^{P}}\left[r_{t+s}^{b H}(j) b_{t+s}^{I}(j)+r_{t+s}^{b E}(j) b_{t+s}^{E}(j)-R_{t+s}^{b} B_{t+s}(j)\right. \\
& \left.-\frac{\kappa_{b H}}{2}\left(\frac{r_{t+s}^{b H}(j)}{r_{t+s-1}^{b H}(j)}-1\right)^{2} r_{t+s}^{b H} b_{t+s}^{I}-\frac{\kappa_{b E}}{2}\left(\frac{r_{t+s}^{b E}(j)}{r_{t+s-1}^{b E}(j)}-1\right)^{2} r_{t+s}^{b E} b_{t+s}^{E}\right]
\end{aligned}
$$

subject to

$$
\begin{aligned}
& b_{t}^{I}(j)=\left(\frac{r_{t}^{b H}(j)}{r_{t}^{b H}}\right)^{-\varepsilon_{t}^{b H}} b_{t}^{I} \\
& b_{t}^{E}(j)=\left(\frac{r_{t}^{b E}(j)}{r_{t}^{b E}}\right)^{-\varepsilon_{t}^{b E}} b_{t}^{E} \\
& B_{t}(j)=b_{t}(j)=b_{t}^{I}(j)+b_{t}^{E}(j)
\end{aligned}
$$

Serupa dengan loan branch, deposit branch mengumpulkan deposito $d_{t}$ dari household dan meneruskannya kepada wholesale unit yang kemudian memberikan suku bunga $r_{t}^{d}$. Utility function dari deposit branch adalah sebagai berikut:

$$
\max _{\left\{r_{t}^{d}(j)\right\}} E_{0} \sum_{s=0}^{\infty}\left(\beta_{P}\right) s \frac{\lambda_{t+s}^{P}}{\lambda_{t}^{P}}\left[R_{t+s}^{D} D_{t+s}(j)-r_{t+s}^{d}(j) d_{t+s}(j)-\frac{\kappa_{d}}{2}\left(\frac{r_{t+s}^{d}(j)}{r_{t+s-1}^{d}(j)}-1\right)^{2} r_{t+s}^{d} d_{t+s}\right]
$$

subject to

$$
\begin{aligned}
& d_{t}(j)=\left(\frac{r_{t}^{d}(j)}{r_{t}^{d}}\right)^{-\varepsilon_{t}^{d}} d_{t} \\
& D_{t}(j)=d_{t}(j)
\end{aligned}
$$

Selain blok perbankan yang dijelaskan di atas, sebagaimana disebutkan sebelumnya, dalam model ini terdapat blok-blok persamaan lain yang mewakili perilaku agen baik rumah tangga, entrepreneur, produsen, retailer, pemerintah, dan bank sentral. Keseluruhan interaksi simultan lintas pasar dan lintas agen tersebut ditutup dengan blok persamaan yang menunjukkan 
market clearing condition. Struktur lengkap dari masing-masing blok persamaan ini tersedia pada penulis.

\section{METODOLOGI}

\subsection{Data dan Variabel}

Untuk keperluan estimasi, digunakan data triwulanan sejak triwulan 1 tahun 2004 sampai dengan triwulan 4 tahun 2011. Data untuk sektor riil yang digunakan untuk estimasi adalah: konsumsi swasta, investasi swasta, pengeluaran pemerintah, ekspor, impor, inflasi CPI, deflator impor, deflator ekspor dan nilai tukar. Untuk data disagregasi PDB, deflator ekspor dan deflator impor digunakan data yang berasal dari publikasi PDB berdasarkan pengeluaran dari BPS. Untuk data nilai tukar dan inflasi CPI didapatkan dari database model ARIMBI/SOFIE. Untuk variabel sektor eksternal, digunakan data yang juga digunakan oleh model ARIMBI dan SOFIE, yaitu PDB dunia, inflasi USA dan LIBOR.

Untuk sektor perbankan, data yang digunakan adalah: suku bunga kebijakan (BI rate), suku bunga dan jumlah penghimpunan Dana Pihak Ketiga (DPK), modal bank, suku bunga dan penyaluran kredit rumah tangga (kredit konsumsi), suku bunga dan jumlah penyaluran kredit ke perusahaan (kredit investasi dan modal kerja), jumlah SBI (dan operasi moneter lainnya) yang dimiliki oleh bank, jumlah tagihan bank kepada pemerintah pusat (SBN), jumlah Reserve (termasuk Cash in Vault) Bank, dan Non Performing Loan (NPL). Untuk komposisi neraca bank, data yang digunakan berasal dari Neraca Analitis Bank Umum. Untuk data NPL didapatkan dari database model SOFIE.

\subsection{Kalibrasi dan Validasi Model}

Sebagaimana model keseimbangan umum stokastik, kriteria kinerja model diukur dari stabilitas, kovergensi, dan akurasi model baik dalam melakukan simulasi maupun peramalan. Model DSGE merupakan model keseimbangan umum dan analisis yang dilakukan tidak terlepas dari nilai keseimbangan jangka panjang atau steady state.

Salah satu teknik penentuan nilai steady state adalah dengan HP filter. Pendekatan ini diaplikasikan pada variabel dalam model seperti komponen neraca bank yang terdiri dari deposit, modal, total pinjaman, penempatan pada SBI, pinjaman ke pemerintah (SBN), dan cadangan yang dimiliki bank. Beberapa nilai steady state variabel diperoleh dari model yang telah ada, seperti nilai steady state variabel suku bunga kebijakan (BI rate) yang mengambil dari model ARIMBI, yaitu 5.75\%. Hal ini dilakukan untuk menjaga konsistensi dengan core model tersebut.

Terkait dengan besaran parameter yang ada dalam model, sebagian paremeter dikalibrasi dengan menggunakan nilai yang digunakan oleh model yang pernah dikembangkan oleh Bank 
Indonesia dan hasil penelitian empiris terkait. Sebagian lainnya mengacu pada studi sebelumnya, seperti CAPU yang mengambil hasil studi Gerali et al (2010), elasticity of subtitution between domestic and foreign goods dan elasticity of subtitution for export goods yang mengacu pada penelitian Zhang dan Verikios (2006) ${ }^{4}$. Selain itu, kalibrasi model juga diperoleh dengan menggunakan hasil estimasi persamaan parsial berdasarkan data selama periode estimasi.

Setelah proses kalibrasi model selesai, maka langkah selanjutnya adalah menguji tingkat akurasi model dengan cara mengamati dinamika dari impulse response yang dihasilkan oleh model. Model DSGE yang dikembangkan dalam paper ini, memungkinkan kita untuk melakukan simulasi dampak shock pada BI rate, dan simulasi dari kebijakan makroprudensial mencakup persyaratan CAR minimum, persyaratan rasio LTV dan rasio Giro Wajib Minimum (GWM). Model ini juga memungkinkan untuk melakukan simulasi dampak shock perbankan seperti komponen yang ada dalam neraca mereka. Terakhir, mengingat model DSGE yang dikembangkan ini merepresentasikan sistem ekonomi yang bersifat terbuka, maka simulasi shock eksternal juga memungkinkan untuk dilakukan.

Mengingat bahwa fokus paper ini adalah membangun model DSGE yang menginternaslisasi sektor perbankan, maka simulasi yang dilakukan dibatasi pada shock BI Rate, reserve requirement, modal bank, dan shock pada default risk perbankan.

\section{HASIL DAN ANALISIS}

\subsection{Kondisi Steady State dan Kalibrasi Model}

Dalam menentukan nilai steady state variabel sektor riil, digunakan data realisasi selama periode estimasi (2001Q1-2011Q4) sebagai acuan utama. Namun, kami juga mempertimbangkan nilai steady state yang digunakan di model DSGE negara maju maupun negara berkembang sebagai perbandingan.

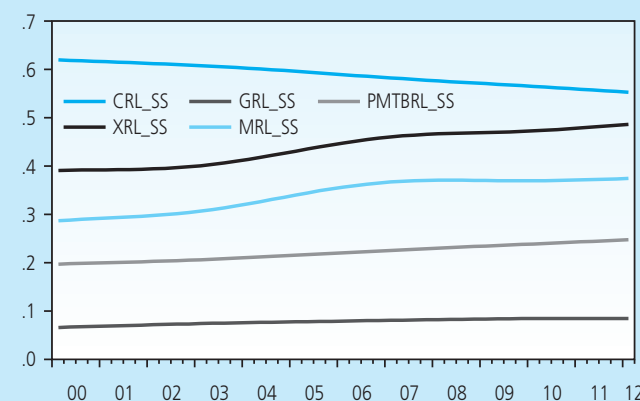

\begin{tabular}{l|r|r|r|r|c} 
& Consumption & Gov & Investment & Export & Import \\
\hline Mean & 0,589 & 0,077309 & 0,220452 & 0,43901 & 0,340948 \\
\hline Median & 0,590 & 0,078438 & 0,220191 & 0,448076 & 0,356237 \\
\hline Maximum & 0,620 & 0,083718 & 0,247197 & 0,48653 & 0,374467 \\
\hline Minimum & 0,553 & 0,06537 & 0,196657 & 0,391218 & 0,286572 \\
\hline Std.Dev. & 0,021 & 0,005743 & 0,01582 & 0,034335 & 0,032558 \\
& Variables & SS Values & & \\
\hline & C & 0,59 \\
\hline & I & 0,22 \\
\hline
\end{tabular}

Grafik 2. Steady State Variabel Disagregasi PDB Berdasarkan Data

4 Digunakan perhitungan parameter berdasarkan CES based estimation yang sesuai dengan asumsi yang digunakan dalam model yang dikembangkan dalam penelitian ini 
Untuk variabel disagregasi PDB, berdasarkan data selama periode estimasi yang telah diproses menggunakan HP Filter didapatkan hasil seperti yang diterlihat di Grafik 2.

Berbeda dengan disagregasi yang dilakukan oleh BPS untuk variabel investasi (investasi bisnis dan investasi bangunan), di dalam model investasi terbagi menjadi 2, yaitu: investasi perumahan dan investasi untuk barang modal. Untuk mendapatkan nilai steady state dari rasio Investasi Perumahan (Housing) dari total PDB kami mengalikan rasio nilai penyelesaian bangunan untuk kategori gedung (0.4) dengan rata-rata rasio investasi bangunan dari total investasi (0.83), kemudian dikalikan lagi dengan rasio investasi terhadap PDB (0.22). Menggunakan pendekatan tersebut (dan pembulatan) kami menetapkan nilai steady state untuk rasio investasi perumahan dari total PDB adalah sebesar 0.08 .

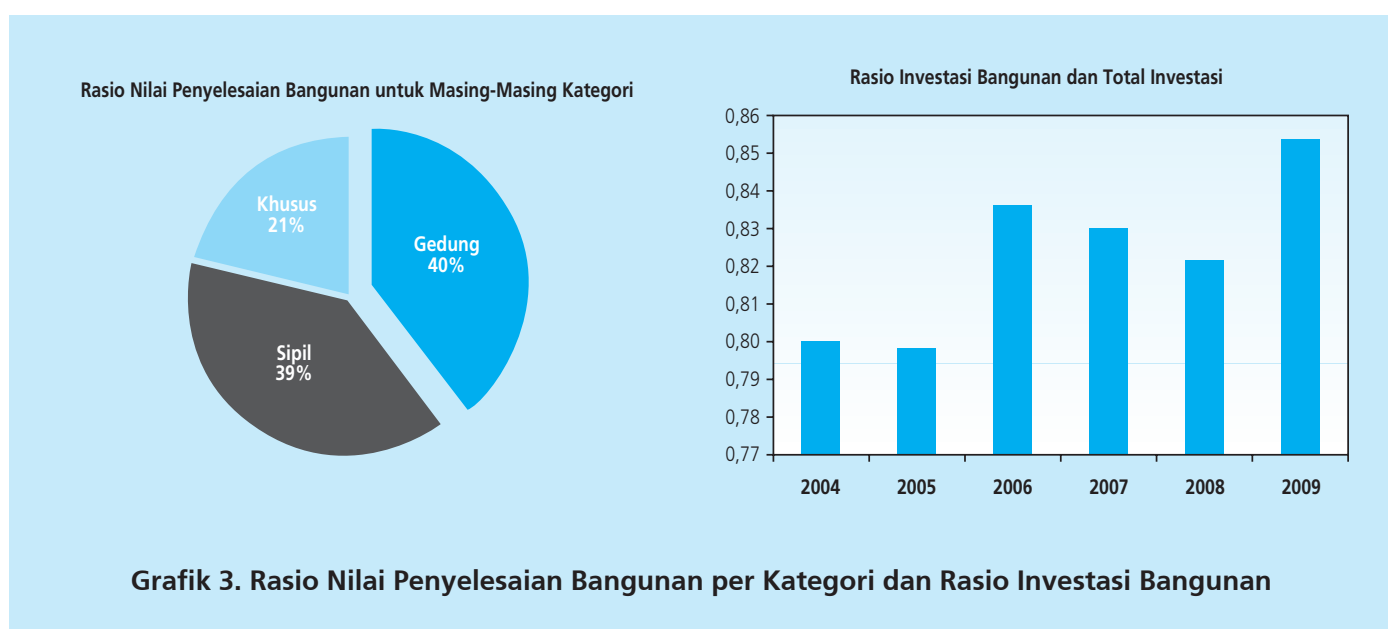

Menggunakan pendekatan yang sama, kita juga bisa mendapatkan nilai steady state untuk variabel komponen neraca bank. Namun, seperti terlihat pada Grafik 4, hasil HP filter untuk rasio variabel komponen neraca bank terhadap total aset tidak menunjukkan kestabilan pada nilai tertentu. Disamping menggunakan hasil HP filter yang ditampilkan pada Grafik 5, digunakan pula hasil penelitian dari Gunadi dan Budiman (2011) mengenai optimalisasi komposisi portofolio bank di Indonesia untuk menentukan nilai steady state variabel neraca bank yang secara lengkap ditampilkan pada Tabel 2 . 

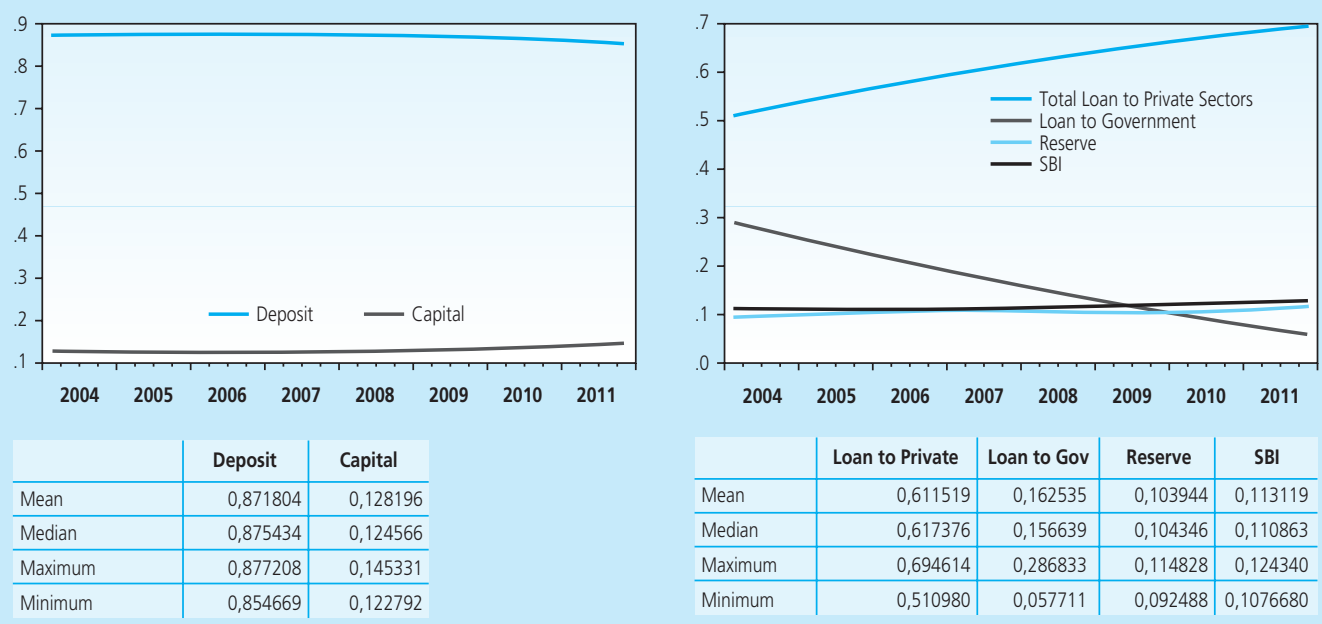

Grafik 4. Hasil HP Filter dari Rasio Variabel Komponen Neraca Bank terhadap Total Aset

\begin{tabular}{l|l|l|r}
\multicolumn{2}{c}{$\begin{array}{c}\text { Tabel 2 } \\
\text { Nilai Steady State Variabel Neraca Bank }\end{array}$} \\
\multicolumn{1}{c|}{ Liabilities } & \multicolumn{1}{|c}{ Assets } \\
Deposit & 0,9 & Total Loan & 0,7 \\
\hline Capital & 0,1 & SBI & 0,12 \\
\hline & & Loan to Government (SBN) & 0,08 \\
\hline & & Reserve & 0,1 \\
\hline
\end{tabular}

Nilai steady state variabel suku bunga kebijakan (BI rate) menggunakan nilai yang sama dengan yang digunakan oleh model ARIMBI, yaitu 5.75\%. Nilai ini cukup berbeda jauh dengan rata-rata dari HP filter $\mathrm{BI}$ rate selama periode estimasi yang sebesar $6.5 \%$. Namun, untuk kebutuhan konsistensi dengan core model ARIMBI, kami menggunakan angka yang lebih rendah tersebut. Apabila kita melihat Grafik 5 yang memperlihatkan hasil HP filter dari berbagai variabel suku bunga dalam model, terlihat bahwa spread antara BI rate dengan suku bunga DPK tidaklah stabil. Di saat BI rate tinggi, spread dengan suku bunga DPK juga besar, sedangkan di saat BI rate rendah, spread dengan suku bunga DPK rendah. Karena kita menggunakan nilai steady state $\mathrm{BI}$ rate yang tergolong rendah maka untuk konsistensi dengan data digunakan spread yang juga rendah untuk menghitung steady state suku bunga DPK. Menggunakan metode ini, kami 
menetapkan nilai steady state suku bunga DPK sebesar 4.5\%. Untuk menentukan nilai steady state suku bunga kredit konsumsi dan investasi, kami menambahkan rata-rata perbedaan antara kedua suku bunga tersebut dengan BI rate selama periode estimasi sehingga didapatkan nilai steady state suku bunga kredit konsumsi sebesar $13.65 \%$ dan nilai steady state suku bunga kredit untuk perusahaan (Modal Kerja dan Investasi) sebesar 11.4\%. Untuk suku bunga LIBOR yang menjadi proksi dari suku bunga luar negeri kami menggunakan angka yang sama dengan yang digunakan model ARIMBI, yaitu 3\%.

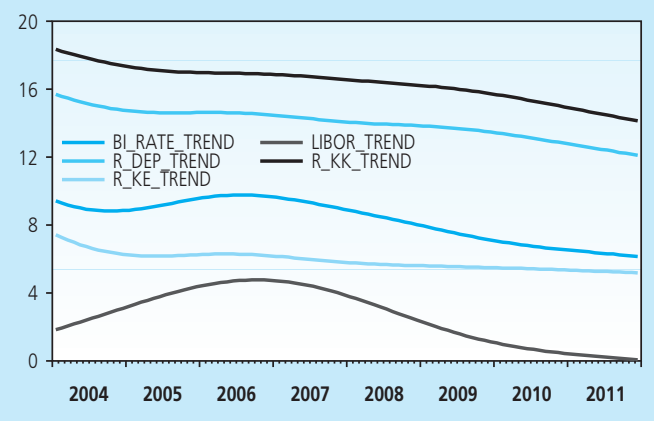

Grafik 5. Hasil HP Filter dari Berbagai Variabel Suku Bunga dalam Model

Secara lengkap, nilai steady state untuk seluruh variabel yang digunakan oleh model terdapat pada Tabel 3.

\begin{tabular}{|c|c|}
\hline \multicolumn{2}{|c|}{$\begin{array}{c}\text { Tabel } 3 \\
\text { Nilai Steady State Seluruh Variabel }\end{array}$} \\
\hline Variables & Assets \\
\hline Consumption to GDP ratio & 0.59 \\
\hline Capital investment to GDP ratio & 0.14 \\
\hline Housing investment to GDP ratio & 0.08 \\
\hline Government expenditure to GDP ratio & 0.09 \\
\hline Import to absorption ratio & 0.38 \\
\hline Export to output ratio & 0.44 \\
\hline Loan to $\mathrm{HH}$ to GDP ratio & 0.31 \\
\hline Loan to entrepreneur to GDP ratio & 0.71 \\
\hline Deposit to GDP ratio & 1.28 \\
\hline Importer's profit margin & 0.11 \\
\hline
\end{tabular}




\begin{tabular}{|c|c|}
\hline Variables & Assets \\
\hline Exporter's profit margin & 0.08 \\
\hline Domestic retailer's profit margin & 0.25 \\
\hline Bl rate * & $5.75 \%$ \\
\hline Rate on loan to $\mathrm{HH}^{*}$ & $13.65 \%$ \\
\hline Rate on loan to entrepreneur* & $11.4 \%$ \\
\hline Rate on deposit* & $4.5 \%$ \\
\hline Foreign interest rate* & $3 \%$ \\
\hline CAR & 0.14 \\
\hline Bank's profit to total asset ratio & 0.2 \\
\hline NPL ratio & 0.3 \\
\hline Deposit to bank's total asset ratio & 0.9 \\
\hline Bank's capital to total asset ratio & 0.1 \\
\hline Loan to bank's total asset ratio & 0.7 \\
\hline Risk free asset to bank's total asset ratio ${ }^{* *}$ & 0.2 \\
\hline Reserve to total asset ratio & 0.1 \\
\hline
\end{tabular}

Sebagian paremeter yang digunakan didalam model dikalibrasi dengan menggunakan nilai yang digunakan oleh model yang pernah dikembangkan oleh Bank Indonesia dan hasil penelitian empiris terkait. Capital share dalam fungsi produksi ditetapkan sebesar 0.54 sesuai dengan hasil estimasi dari model MODBI 2012. CAPU parameter menggunakan nilai yang juga digunakan oleh Gerali et al (2010). Nilai dari home bias parameter ditentukan berdasarkan nilai HP filter dari import to absorption ratio Indonesia selama periode estimasi. Parameter yang menentukan elasticity of subtitution between domestic and foreign goods dan elasticity of subtitution for export goods menggunakan nilai yang berasal dari penelitian Zhang dan Verikios $(2006)^{5}$. Nilai parameter untuk risk premium dan yang mengatur biaya untuk mengelola modal bank didapatkan melalui hubungan steady state antara berbagai variabel yang terdapat dalam model. Calvo parameter untuk labor mengikuti hasil estimasi dari model BISMA (2009). Untuk parameter dari persamaan ad hoc yang menentukan dinamika dari bobot aset beresiko dan reserve yang dimiliki bank menggunakan hasil estimasi persamaan parsial berdasarkan data selama periode estimasi.

5 Digunakan perhitungan parameter berdasarkan CES based estimation yang sesuai dengan asumsi yang digunakan dalam model yang dikembangkan dalam penelitian ini 


\begin{tabular}{|c|c|c|}
\hline \multicolumn{3}{|l|}{$\begin{array}{c}\text { Tabel } 4 \\
\text { Nilai Parameter Hasil Kalibrasi }\end{array}$} \\
\hline \multicolumn{2}{|l|}{ Parameters } & \multirow{2}{*}{$\begin{array}{c}\text { Values } \\
11\end{array}$} \\
\hline Mark-up parameter in labor market & $\varepsilon_{\mathrm{w}}$ & \\
\hline Depreciation rate of capital & $\delta_{k}$ & 0.025 \\
\hline Depreciation rate of housing asset & $\delta_{\chi}$ & 0.0125 \\
\hline Cost to managing bank's capital & $\delta_{\mathrm{b}}$ & 0.1 \\
\hline CAPU parameter 1 & $\xi_{1}$ & 0.08 \\
\hline CAPU parameter 2 & $\xi_{2}$ & 0.008 \\
\hline Risk premium parameter & $\rho^{\mathrm{b}}$ & 0.11 \\
\hline Capital share in production function & $\alpha$ & 0.54 \\
\hline Home bias parameter & $\eta$ & 0.62 \\
\hline Elasticity of subtitution between domestic and foreign goods & $\mu$ & 0.63 \\
\hline Elasticity of subtitution for export goods & $\mu_{H^{*}}$ & 0.45 \\
\hline Labour income share of unconstrained household & $\mu_{\mathrm{L}}$ & 0.67 \\
\hline $\begin{array}{l}\text { The probability of given labor (from patient and impatient } \mathrm{HH} \text { ) is selected not to } \\
\text { reoptimize its wage }\end{array}$ & $\theta_{\text {wp }}$ dan $\theta_{\text {wi }}$ & 0.65 \\
\hline Risky weight equation's parameter 1 & $\rho^{\omega}$ & 0.567 \\
\hline Risky weight equation's paremeter 2 & $\alpha_{\mathrm{a}}$ & 0.434 \\
\hline Risky weight equation's parameter 3 & $\alpha_{b}$ & 0.784 \\
\hline Reserve equation's parameter & $\rho_{\Gamma}$ & 0.197 \\
\hline Excess reserve equation's parameter & $\rho_{\varepsilon}$ & 0.632 \\
\hline
\end{tabular}

Penentuan prior untuk parameter yang diestimasi menggunakan pendekatan yang sama dengan penentuan parameter yang dikalibrasi, yaitu menggunakan nilai dari model yang pernah dikembangkan sebelumnya ataupun dari penelitian empiris terkait. Untuk parameter $K_{d}, K_{b e}$ dan $K_{b i}$, prior ditentukan dengan menetapkan respon suku bunga retail bank terhadap shock suku bunga kebijakan sesuai dengan hasil estimasi dari immediate pass-through yang dilakukan oleh Harmanta dan Purwanto (2012). Untuk Taylor rule parameter $\left(\varphi_{r}, \varphi_{\pi}\right.$ dan $\left.\varphi_{y}\right)$, nilai dari prior ditetapkan sesuai dengan nilai yang digunakan oleh core model ARIMBI. Prior untuk parameter yang mengatur habit persistence dalam kegiatan konsumsi rumah tangga menggunakan hasil estimasi model BISMA (2009). Secara lengkap, prior distribution, jenis distribusi dan posterior distribution dari parameter hasil estimasi terdapat pada Tabel 5. 


\begin{tabular}{|c|c|c|c|c|c|c|c|}
\hline \multirow{3}{*}{ Parameters } & \multicolumn{4}{|c|}{$\begin{array}{c}\text { Tabel } 5 \\
\text { Nilai Parameter Hasil Estimasi }\end{array}$} & & & \\
\hline & & \multirow{2}{*}{ Distributions } & \multicolumn{2}{|c|}{ Prior Distribution } & \multicolumn{3}{|c|}{ Posterior Distribution } \\
\hline & & & Mean & Std. Dev. & Mean & $2.5 \%$ & $97.5 \%$ \\
\hline $\begin{array}{l}\text { Inverse of intertemporal elasticity of } \\
\text { substitution for housing }\end{array}$ & $\sigma_{\chi}$ & normal & 2 & 0.5 & 3.6357 & 3.5297 & 3.7737 \\
\hline $\begin{array}{l}\text { Inverse of intertemporal elasticity of } \\
\text { substitution for consumption }\end{array}$ & $\sigma_{c}$ & normal & 2 & 0.1 & 2.1950 & 1.0419 & 1.2683 \\
\hline $\begin{array}{l}\text { Inverse of Frisch elasticity of } \\
\text { labour supply }\end{array}$ & $\sigma_{\mathrm{n}}$ & normal & 2 & 0.1 & 1.3663 & 1.3639 & 1.3694 \\
\hline $\begin{array}{l}\text { Adjustment cost paremeter for } \\
\text { deposit rate }\end{array}$ & $\mathrm{K}_{\mathrm{d}}$ & gamma & 3.25 & 0.2 & 3.2285 & 3.1799 & 3.2675 \\
\hline $\begin{array}{l}\text { Adjustment cost paremeter for } \\
\text { entrepreneur loan rate }\end{array}$ & $\mathrm{K}_{\mathrm{be}}$ & normal & 3.5 & 0.2 & 3.6945 & 3.6299 & 3.7420 \\
\hline $\begin{array}{l}\text { Adjustment cost paremeter for } \\
\text { household loan rate }\end{array}$ & $\mathrm{K}_{\mathrm{bi}}$ & normal & 8 & 0.2 & 8.1280 & 8.0775 & 8.1676 \\
\hline $\begin{array}{l}\text { Adjustment cost paremeter for } \\
\text { capital investment }\end{array}$ & $\mathrm{K}_{\mathrm{k}}$ & gamma & 2 & 0.2 & 0.9811 & 0.9777 & 0.9855 \\
\hline $\begin{array}{l}\text { Adjustment cost paremeter for } \\
\text { housing investment }\end{array}$ & $\mathrm{K}_{\chi}$ & normal & 2 & 0.5 & 3.6510 & 3.5496 & 3.7510 \\
\hline $\begin{array}{l}\text { Adjustment cost paremeter for } \\
\text { bank's CAR }\end{array}$ & $\mathrm{K}_{\mathrm{kb}}$ & beta & 2 & 0.2 & 1.7823 & 1.7208 & 1.8217 \\
\hline Calvo paremeter for import goods & $\theta_{\mathrm{f}}$ & beta & 0.5 & 0.05 & 0.5707 & 0.5616 & 0.5776 \\
\hline Calvo paremeter for domestic goods & $\theta_{\mathrm{h}}$ & beta & 0.5 & 0.05 & 0.4996 & 0.4890 & 0.5167 \\
\hline Calvo parameter for export goods & $\theta_{\mathrm{h}}{ }^{*}$ & beta & 0.5 & 0.05 & 0.4149 & 0.4075 & 0.4264 \\
\hline $\begin{array}{l}\text { Interest rate smoothing parameter } \\
\text { in Taylor rule }\end{array}$ & $\varphi_{\mathrm{r}}$ & beta & 0.75 & 0.01 & 0.7412 & 0.7379 & 0.7436 \\
\hline $\begin{array}{l}\text { Inflation weight parameter in } \\
\text { Taylor rule }\end{array}$ & $\varphi_{\pi}$ & gamma & 1.9 & 0.01 & 1.8957 & 1.8929 & 1.8980 \\
\hline $\begin{array}{l}\text { Output gap parameter in Taylor rule } \\
\text { Habit persistence parameter in }\end{array}$ & $\varphi_{y}$ & normal & 0.25 & 0.01 & 0.2548 & 0.2531 & 0.2562 \\
\hline consumption & $\xi$ & beta & 0.6 & 0.05 & 0.4887 & 0.4770 & 0.5038 \\
\hline
\end{tabular}

\subsection{Validasi Model}

Bagian ini menganalisis dinamika dari impulse response yang dihasilkan oleh model sebagai bagian dari proses validasi model. Sebagaimana disebutkan sebelumnya, simulasi dibatasi pada dampak dari perubahan BI rate, reserve requirement, dan default risk. 


\section{Shock BI Rate}
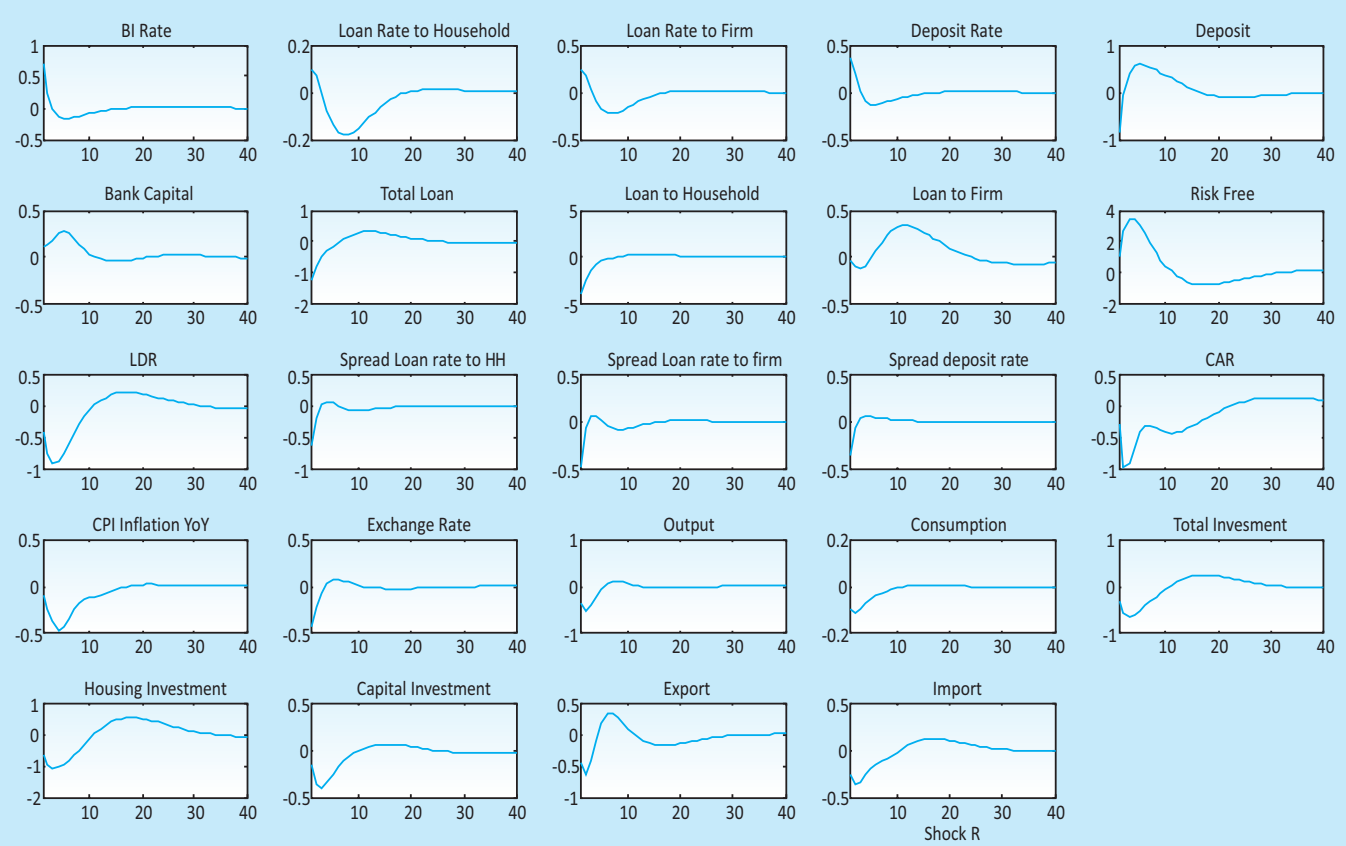

Grafik 6. Impulse Response Shock BI Rate

Kenaikan $\mathrm{BI}$ rate sebesar 1\% akan ditransmisikan ke berbagai suku bunga yang ada di sektor perbankan. Besarnya kenaikan suku bunga ini disesuaikan dengan besarnya mark-up dan tingkat stickiness dari masing-masing suku bunga. Suku bunga deposito naik lebih tinggi dari suku bunga pinjaman, karena memiliki nilai mark-down dan tingkat stickiness yang juga paling kecil. Walaupun Bank menerapkan nilai mark-up yang tinggi terhadap suku bunga pinjaman pada rumah tangga (kredit konsumsi), namun tingkat stickiness dari suku bunga tersebut juga sangat tinggi. Hal ini menyebabkan suku bunga pinjaman rumah tangga naik hanya sebesar $0.1 \%$. Dengan adanya stickiness ini, terlihat bahwa spread suku bunga pinjaman $\mathrm{HH}$ terhadap $\mathrm{BI}$ rate mengalami penurunan sekitar 0.6\%. Penurunan spread ini hanya terjadi selama 3 periode, dan akan kembali ke posisi steady state-nya di periode ke-4. Hal yang sama juga terjadi pada suku bunga pinjaman entrepreneur yang naik sebesar $0.2 \%$. Dengan kenaikan yang hanya sebesar $0.2 \%$, maka spread suku bunga pinjaman entrepreneur terhadap $\mathrm{BI}$ rate juga mengalami penurunan sekitar $0.4 \%$. Penurunan spread ini hanya terjadi selama 2 periode, dan akan kembali ke kondisi steady state-nya di periode ke-3. Kenaikan suku bunga pinjaman akan direspon dengan penurunan penyaluran pinjaman, akibat turunnya demand 
dari rumah tangga maupun entrepreneur. Secara total, penyaluran pinjaman oleh perbankan mengalami penurunan sebesar $1 \%$ (di titik terendah). Penurunan penyaluran pinjaman ini membuat bank harus mengalihkan sebagian dana yang dimilikinya ke dalam risk free asset (naik sekitar 3.5\%). Penurunan penyaluran pinjaman juga menyebabkan bank mengalami penurunan LDR sekitar $1 \%$.

Peningkatan yang terjadi pada suku bunga deposito dan suku bunga pinjaman untuk rumah tangga menyebabkan terjadinya penurunan konsumsi. Peningkatan yang terjadi pada suku bunga pinjaman, baik untuk rumah tangga maupun untuk perusahaan menyebabkan penurunan pada investasi barang modal dan aset perumahan. Selain itu, peningkatan yang terjadi pada suku bunga pinjaman juga menyebabkan apresiasi nilai tukar yang akan berakibat pada penurunan ekspor. Impor juga ikut mengalami penurunan akibat berkurangnya permintaan untuk kebutuhan konsumsi dan investasi.

\section{Reserve Requirement}

Kenaikan reserve requirement rate (GWM) sebesar 1\% akan direspon oleh bank dengan menurunkan suku bunga deposito, sesuai dengan FOC dari utility function sektor perbankan. Hal ini akan menyebabkan sedikit penurunan pada jumlah deposito yang dikumpulkan bank. Seiring dengan menurunnya loanable fund yang dimiliki oleh bank, maka bank melakukan pengalihan aset dari yang tergolong risk free ke aset yang memiliki nilai return yang lebih besar, yaitu pinjaman kepada rumah tangga dan entrepreneur. Hal ini membuat perubahan yang terjadi terhadap total pinjaman yang disalurkan oleh sektor perbankan tidaklah begitu besar. Tanpa adanya perubahan yang signifikan terhadap jumlah deposito yang dihimpun dan jumlah pinjaman yang disalurkan, maka nilai LDR maupun CAR juga tidak banyak mengalami perubahan. LDR dalam jangka pendek mengalami peningkatan karena terjadi peningkatan penyaluran pinjaman akibat terjadinya pengalihan dari aset yang tergolong risk free. CAR mengalami sedikit kenaikan, karena keuntungan bank mengalami peningkatan akibat penempatan pada aset yang memiliki return yang lebih tinggi. Tidak signifikannya perubahan jumlah deposito yang dihimpun dan jumlah pinjaman yang disalurkan oleh perbankan menyebabkan pengaruh dari shock rasio GWM terhadap variabel sektor riil (GDP, inflasi dan nilai tukar) juga tidak terlalu signifikan. 

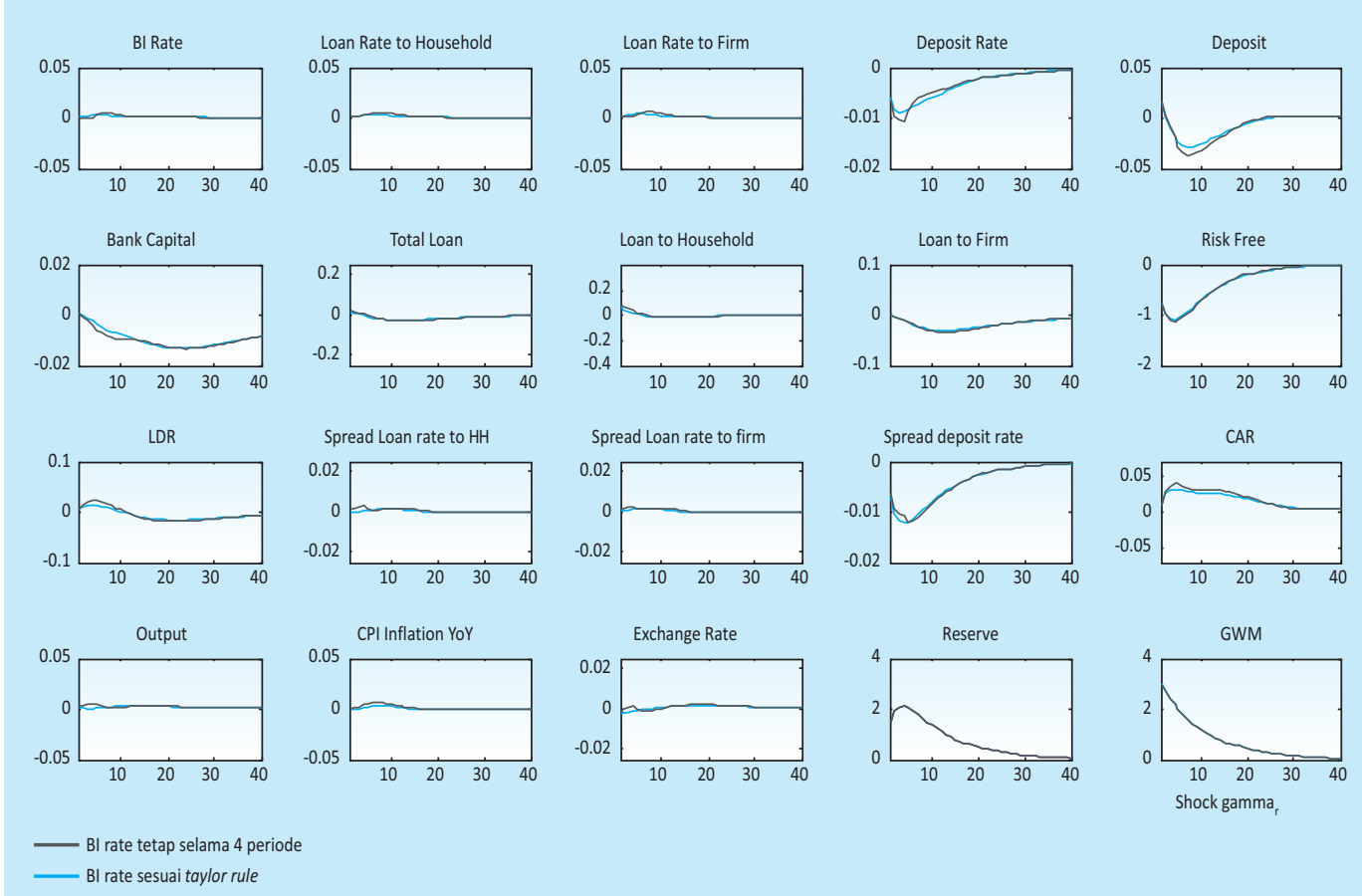

Grafik 7. Impulse Response Shock Reserve Requiement
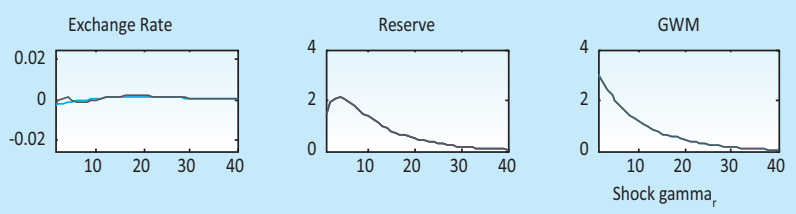

BI rate tetap selama 4 pe

\section{Modal Bank}

Ketika terjadi shock penurunan modal bank, bank akan bereaksi dengan menurunkan penyaluran pinjaman. Hal ini akan menyebabkan penurunan PDB dan inflasi. Bank sentral perlu memberikan stimulus berupa penurunan suku bunga kebijakan untuk menghindari penurunan PDB yang lebih besar. 

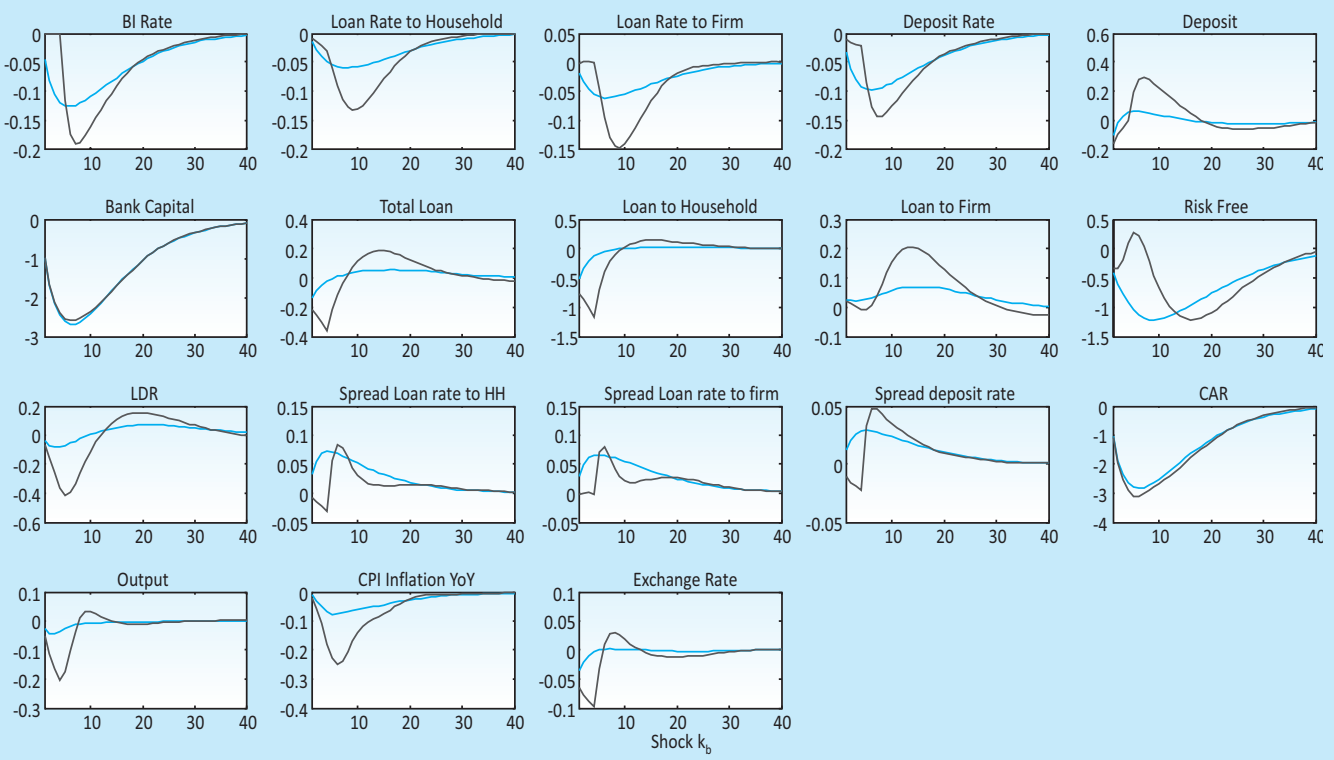

BI rate tetap selama 4 periode

BI rate sesuai taylor rule

Grafik 8. Impulse Response Shock Bank Capital

\section{Default Risk}

Peningkatan default risk sebesar $1 \%$ akan direspon oleh bank dengan melakukan penurunan penyaluran pinjaman dan peningkatan risk free asset yang dimiliki. Penurunan penyaluran pinjaman oleh bank akan menyebabkan turunnya LDR. Dengan meningkatnya default risk, CAR yang dimiliki Bank akan berkurang akibat meningkatnya bobot risiko dalam perhitungan ATMR. Secara umum, dapat terlihat bahwa pergerakan berbagai komponen neraca bank tidaklah terlalu signifikan. Untuk memperbaiki respon berbagai variabel dalam model akibat shock dari default risk, telah dicoba juga untuk membuat persamaan NPL menjadi pro-cyclical untuk membuat mekanisme "semi" financial accelerator. Namun, karena jalur pengaruh dari default risk hanyalah melalui perhitungan bobot risky asset yang juga sangat tergantung dari pilihan portofolio aset bank pada saat itu maka pengaruh pro-cyclicality-nya juga tidak begitu terasa. Untuk pengembangan lebih lanjut dan untuk memperbaiki impulse response untuk default risk shock dan LTV pinjaman entrepeneur, akan dimodelkan pengaruh dari default risk tersebut kepada nilai mark-up dari loan yang ditetapkan oleh bank. 

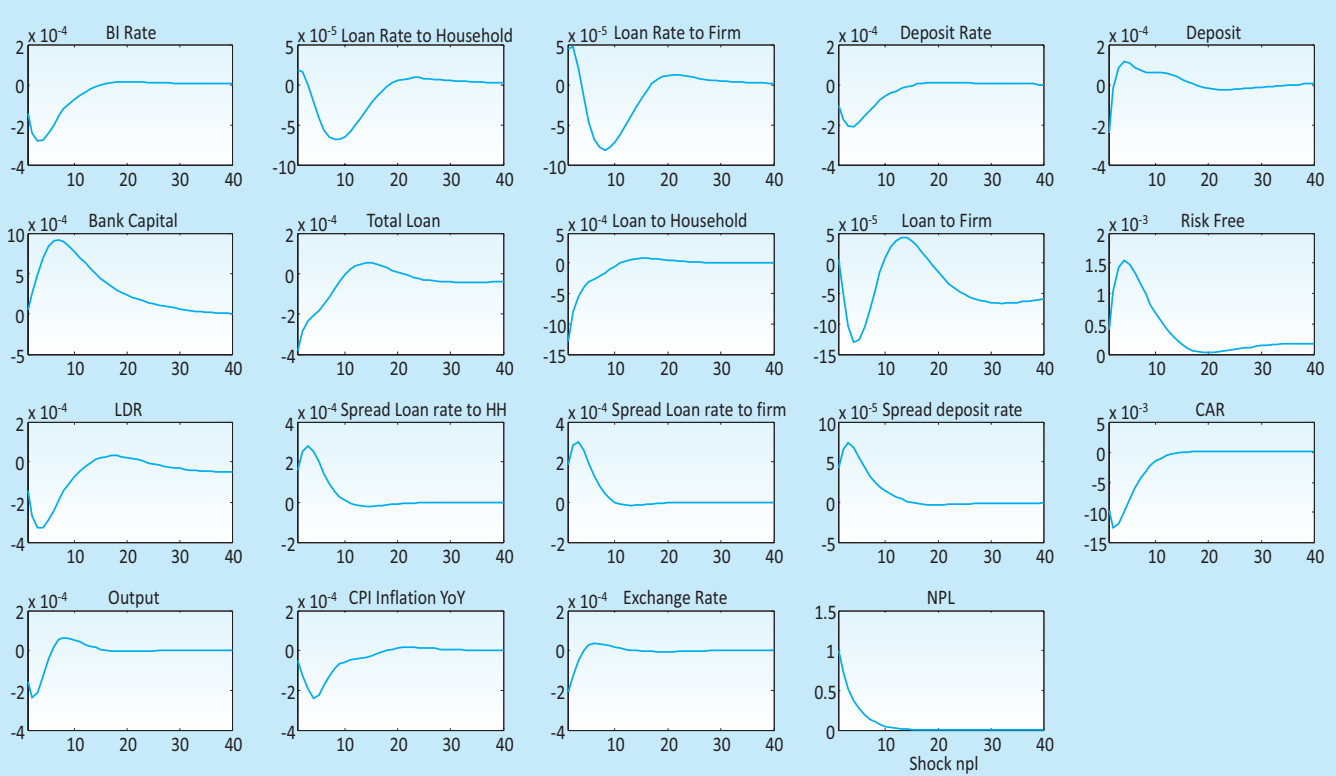

Grafik 9. Impulse Response Shock NPL's Shock

\section{KESIMPULAN}

Dalam penelitian ini dibangun model DSGE untuk perkenomian terbuka (small open economy) yang telah dilengkapi oleh financial frictions berupa collateral constraints dan sektor perbankan yang didesain sesuai dengan kondisi Indonesia. Model yang dibangun pada penelitian ini telah mampu memenuhi tujuan pengembangannya, yaitu melakukan simulasi kebijakan moneter (BI rate) dan kebijakan makroprudensial (GWM, CAR dan LTV requirement). Terdapat satu caveat yang perlu diingat terkait dengan interpretasi hasil simulasi dari shock LTV ratio requirement yang dihasilkan oleh model. Definisi dan asumsi dari LTV ratio requirement yang terdapat dalam model tidak sepenuhnya bisa disejajarkan dengan konsep LTV ratio requirement yang telah diterapkan di Indonesia baru-baru ini (tahun 2012) sehingga hasil simulasi model harus diintrepretasikan secara lebih hati-hati.

Dengan memasukkan sektor perbankan di dalam model maka dimungkinkan pula untuk melakukan analisa kebijakan yang diperlukan untuk menghadapi shock yang berasal dari sektor perbankan. Ketika terjadi penurunan modal bank secara tiba-tiba (akibat write-off yang cukup besar pada aset yang dimiliki), maka bank sentral perlu memberikan stimulus berupa penurunan $\mathrm{BI}$ rate di saat yang sama ketika terjadi shock. Penundaan penurunan BI rate oleh bank sentral 
akan menyebabkan penurunan output yang jauh lebih besar yang membutuhkan stimulus kebijakan moneter yang juga jauh lebih besar. Hasil simulasi ini meng-highlight pentingnya kebijakan moneter yang dilaksanakan tepat waktu untuk menghadapi shock yang berasal dari sektor perbankan.

Analisa impulse reponse dari simulasi atas peningkatan $\mathrm{BI}$ rate dan perubahan reserve requirement ratio, dan default risk, menunjukkan bahwa model DSGE yang dibangun ini adalah valid untuk digunakan. Hasil simulasi menunjukkan bahwa peningkatan BI rate akan menyebabkan bank meningkatkan suku bunga retail-nya, mengurangi penyaluran pinjaman dan meningkatkan aset yang bersifat risk free. Hal ini kemudian akan menyebabkan turunnya PDB dan inflasi. Pada sisi lain, kondisi ekses likuiditas di sektor perbankan Indonesia membuat kenaikan yang terjadi pada reserve requirement ratio yang ditetapkan oleh bank sentral tidak memiliki pengaruh yang signifikan terhadap sektor riil. Hal ini karena berkurangnya likuiditas yang disebabkan oleh meningkatnya reserve bank dapat ditutupi oleh bank dengan mengurangi risk free asset yang dimilikinya, sehingga tidak terjadi perubahan yang signifikan terhadap total pinjaman yang disalurkan oleh bank.

Terkait default risk, simulasi yang dilakukan adalah memberikan shock positif sebesar $1 \%$ atas resiko default. Hasil yang diperoleh menunjukkan bahwa shock ini akan direspon oleh bank dengan melakukan penurunan penyaluran pinjaman dan peningkatan risk free asset yang dimiliki. Meski demikian, hasil simulasi ini menunjukkan dampak terbatas dari pengaruh default risk terhadap dinamika dari penentukan suku bunga pinjaman dan jumlah penyaluran pinjaman oleh bank. Pendekatan collateral constraint memang tidak memasukkan default risk sebagai bagian dari dinamika penentuan suku bunga dan jumlah penyaluran kredit. Persamaan ad hoc yang ditambahkan pada model yang menghubungkan default risk dengan dinamika dari CAR sektor perbankan tidak cukup signifikan peranannya. Mencermati hal ini, maka kedepan, yang dapat dilakukan antara lain adalah dengan mengadopsi sebagian atau seluruh konsep financial friction berupa financial accelerator ala BGG ke dalam model.

Berdasarkan proses validasi model melalui simulasi, maka potensi pengembangan lain yang perlu dilakukan adalah sebagai berikut:

a) Pengembangan model untuk mendukung aplikasi yang lebih luas terkait dengan interaksi antara berbagai kebijakan moneter dan kebijakan makroprudensial. Hal yang dapat dilakukan antara lain dengan memodelkan CAR requirement rule, LTV requirement rule dan interaksinya terhadap Taylor Rule.

b) Pengembangan lebih lanjut dari sektor eksternal dari model untuk dapat melakukan simulasi shock variabel eksternal yang lebih luas seperti shock harga minyak dunia, shock komoditas non migas dunia dan shock terkait country risk premium.

c) Pengembangan model untuk digunakan tidak hanya sebagai model untuk kebutuhan simulasi namun juga untuk kebutuhan proyeksi variabel makro maupun variabel yang terkait dengan neraca dan kondisi sektor perbankan. 


\section{DAFTAR PUSTAKA}

Adolfson, Malin \& Laséen, Stefan \& Lindé, Jesper \& Villani, Mattias, 2005. "Bayesian Estimation of an Open Economy DSGE Model with Incomplete Pass-Through," Working Paper Series 179, Sveriges Riksbank (Central Bank of Sweden).

Agung, Juda ,2010."Mengintegrasikan Kebijakan Moneter dan Makroprudential: Menuju Paradigma Baru Kebijakan Moneter di Indonesia Pasca Krisis Global". Bank Indonesia Working Paper No.WP/07/2010.

Angelini, Paolo \&Andrea Enria\&Stefano Neri\&Fabio Panetta \&Mario Quagliariello, 2010. "Procyclicality of capital regulation: is it a problem? How to fix it?", Questioni di Economia e Finanza (Occasional Papers) 74, Bank of Italy, Economic Research and International Relations Area.

Angelini, Paolo \&Stefano Neri \&Fabio Panetta, 2011. "Monetary and macroprudential policies", Temi di discussione (Economic working papers) 801, Bank of Italy, Economic Research and International Relations Area.

Bank Indonesia, 2006, "General Equilibrium Model Bank Indonesia 2006," Bank Indonesia Working Paper.

Bank Indonesia .2009, "Bank Indonesia Structural Macromodel" Bank Indonesia Working Paper.

BIS, 2010. "Macroprudential instruments and frameworks: A stocktaking of issues and experiences. Committee on The Global Financial System.

Brzoza-Brzezina, Michå̊, \&Krzysztof Makarski, 2011, "Credit crunch in a small open economy," Journal of International Money and Finance, Elsevier, vol. 30(7), pages 14061428.

Camilo E Tovar, 2008. "DSGE models and central banks," BIS Working Papers 258, Bank for International Settlements.

Gerali, Andrea \& Stefano Neri \& Luca Sessa \& Federico M. Signoretti, 2010, "Credit and banking in a DSGE model of the euro area,"Temi di discussione (Economic working papers) 740, Bank of Italy, Economic Research and International Relations Area.

Gunadi, Iman\&Advis Budiman ,2011, "Optimalisasi Komposisi Portfolio Bank di Indonesia", Kajian Stabilitas Keuangan No. 17, September.

Harmanta \& Nur Purwanto, 2012, "Stickiness Suku Bunga retail Perbankan di Indonesia ", Catatan Riset No. 14/ 39 /DKM/BRE/CR, Bank Indonesia, Desember. 
lacoviello, M. ,2005, "House Prices, Borrowing Constraints and Monetary Policy in the Business Cycle" American Economic Review, Vol. 95(3), pp. 739-764.

Lawrence J. Christiano \& Martin Eichenbaum \& Charles L. Evans, 2005. "Nominal Rigidities and the Dynamic Effects of a Shock to Monetary Policy," Journal of Political Economy, University of Chicago Press, vol. 113(1), pages 1-45, February.

Liu, Zheng \& Pengfei Wang \& Tao Zha, 2010. "Do credit constraints amplify macroeconomic fluctuations?", Working Paper 2010-01, Federal Reserve Bank of Atlanta.

Vlcek, Jan \& Scott Roger, 2012. "Macrofinancial Modeling at Central Banks: Recent Developments and Future Directions," IMF Working Papers 12/21, International Monetary Fund.

Zhang, X. \& Verikios, G. ,2006, "A rmington Parameter Estimation for a Computable General Equilibrium Model: A Database Consistent Approach", Economics Discussion Working Papers No. 06-10, The University of Western Australia,Department of Economics. Zhang and Verikios (2006). 


\section{LAMPIRAN}

\section{Prior - Posterior Graphs}
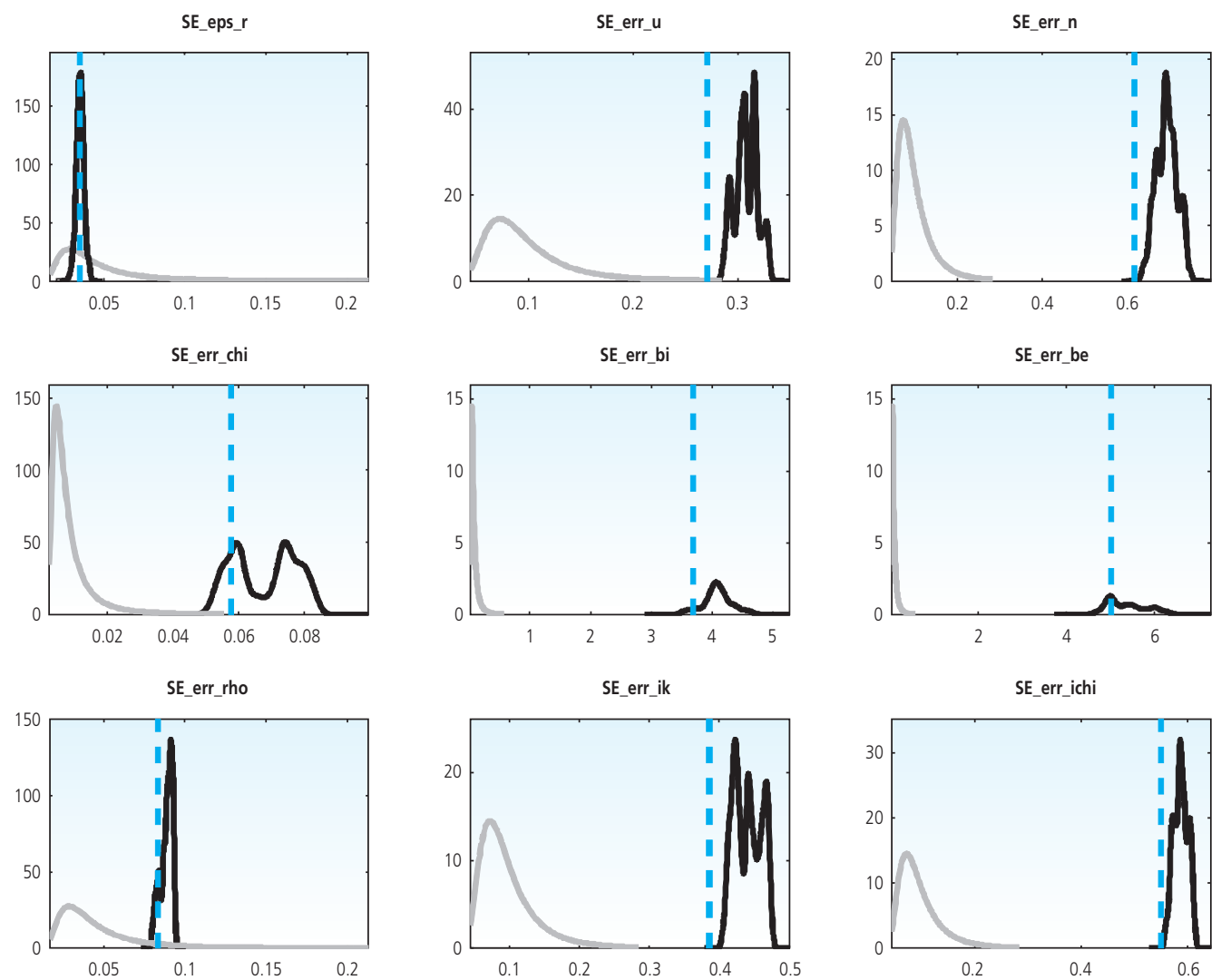

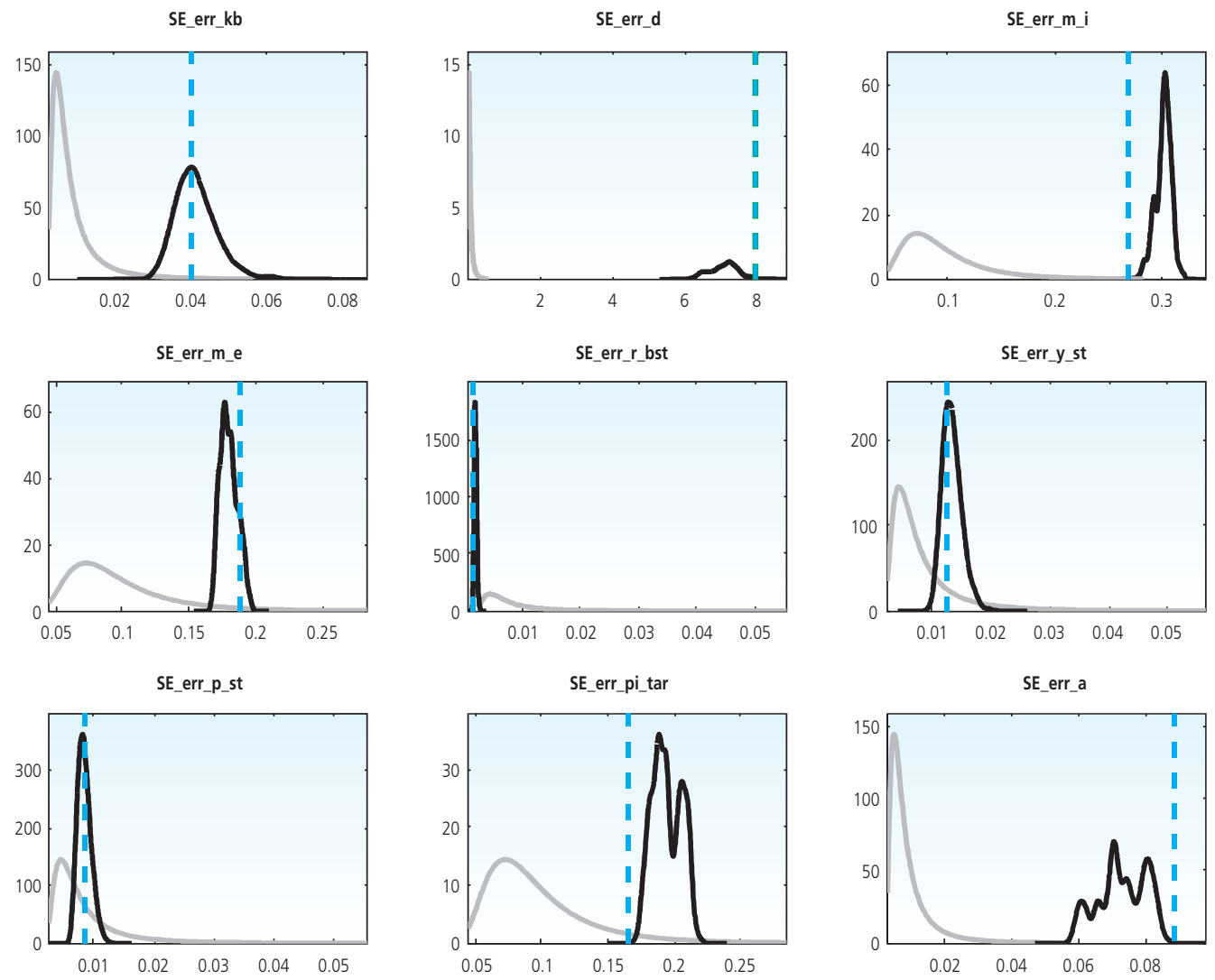


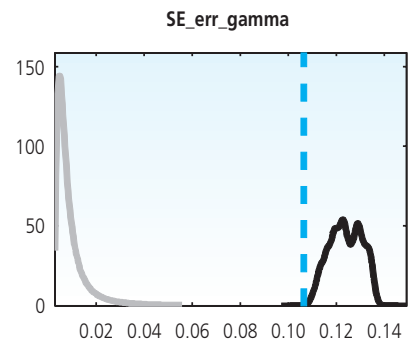

SE_err_bg

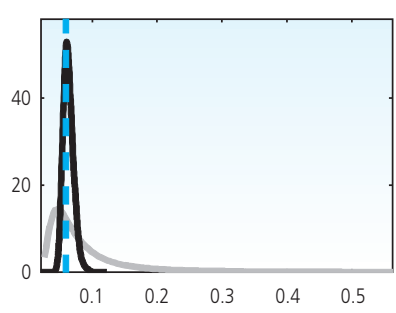

SE_err_npl

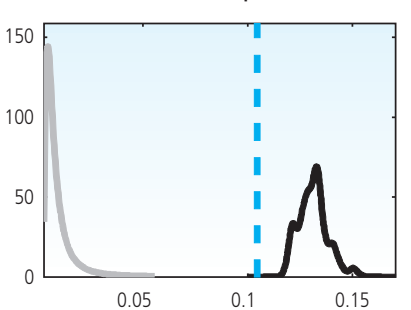

SE_err_nu_b

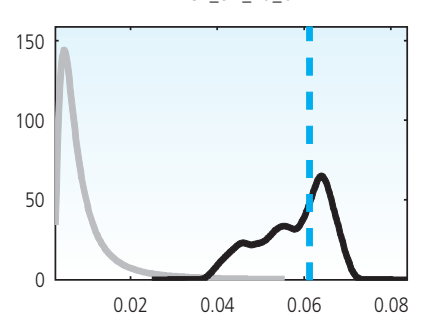

SE_err_g

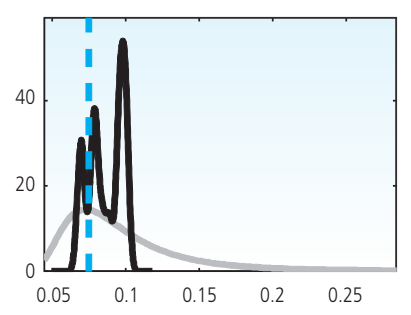

SE_err_gamma_r

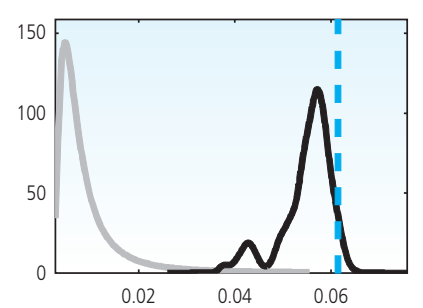

SE_err_bst

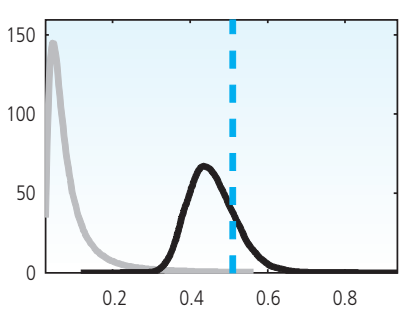

SE_err_omega_b

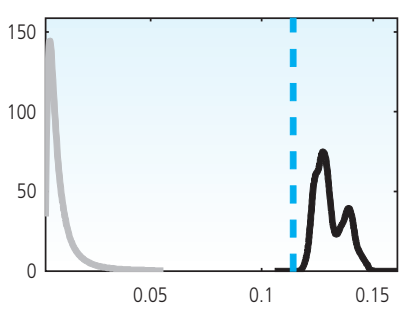

SE_err_p_f_st

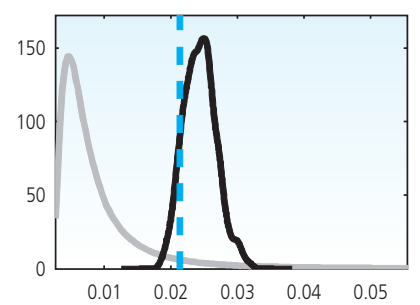



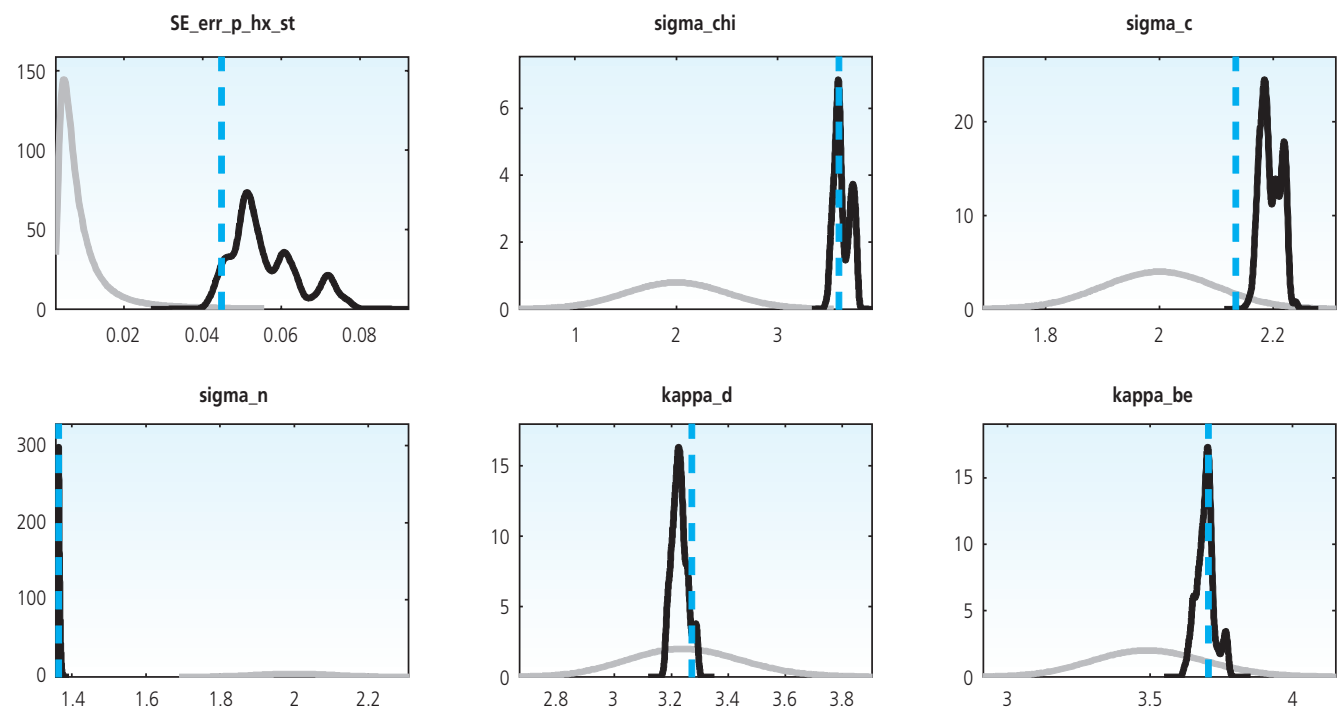

kappa_bi
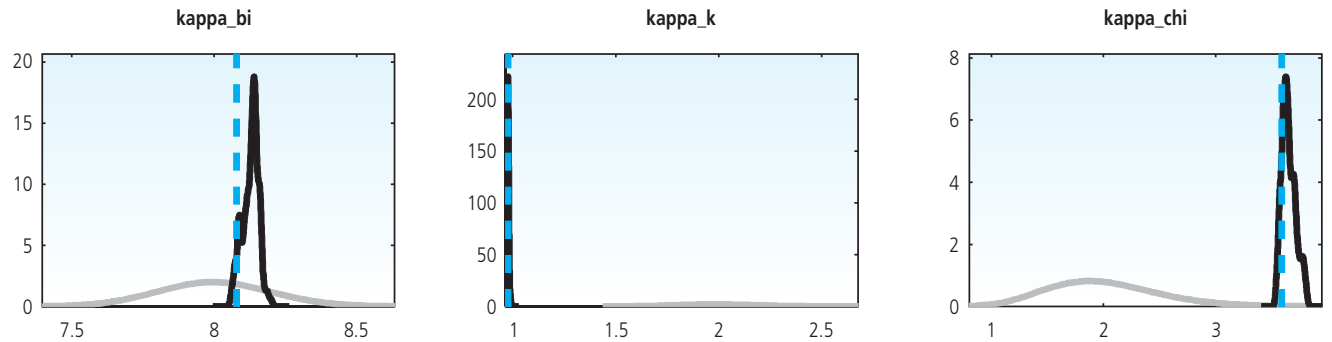

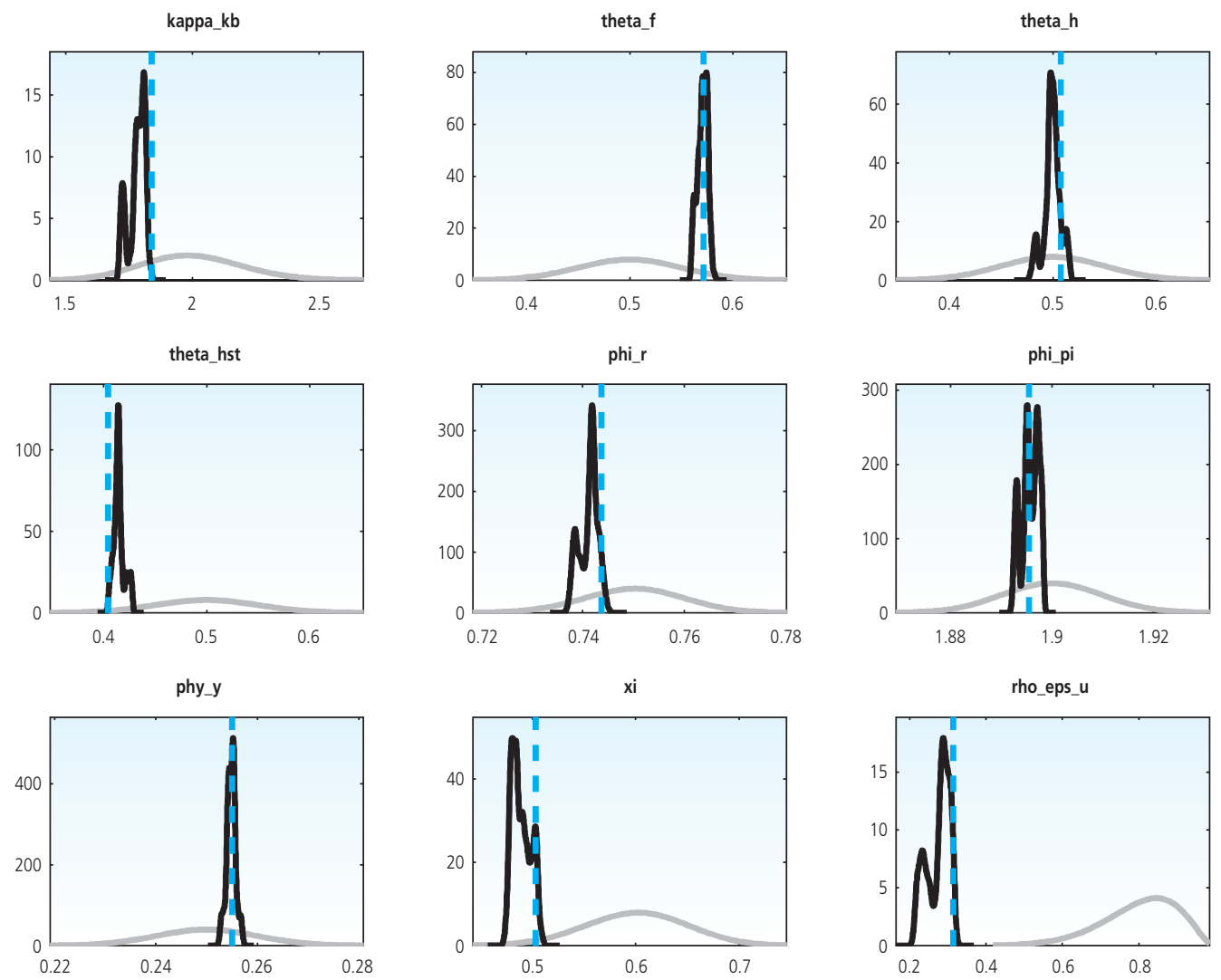

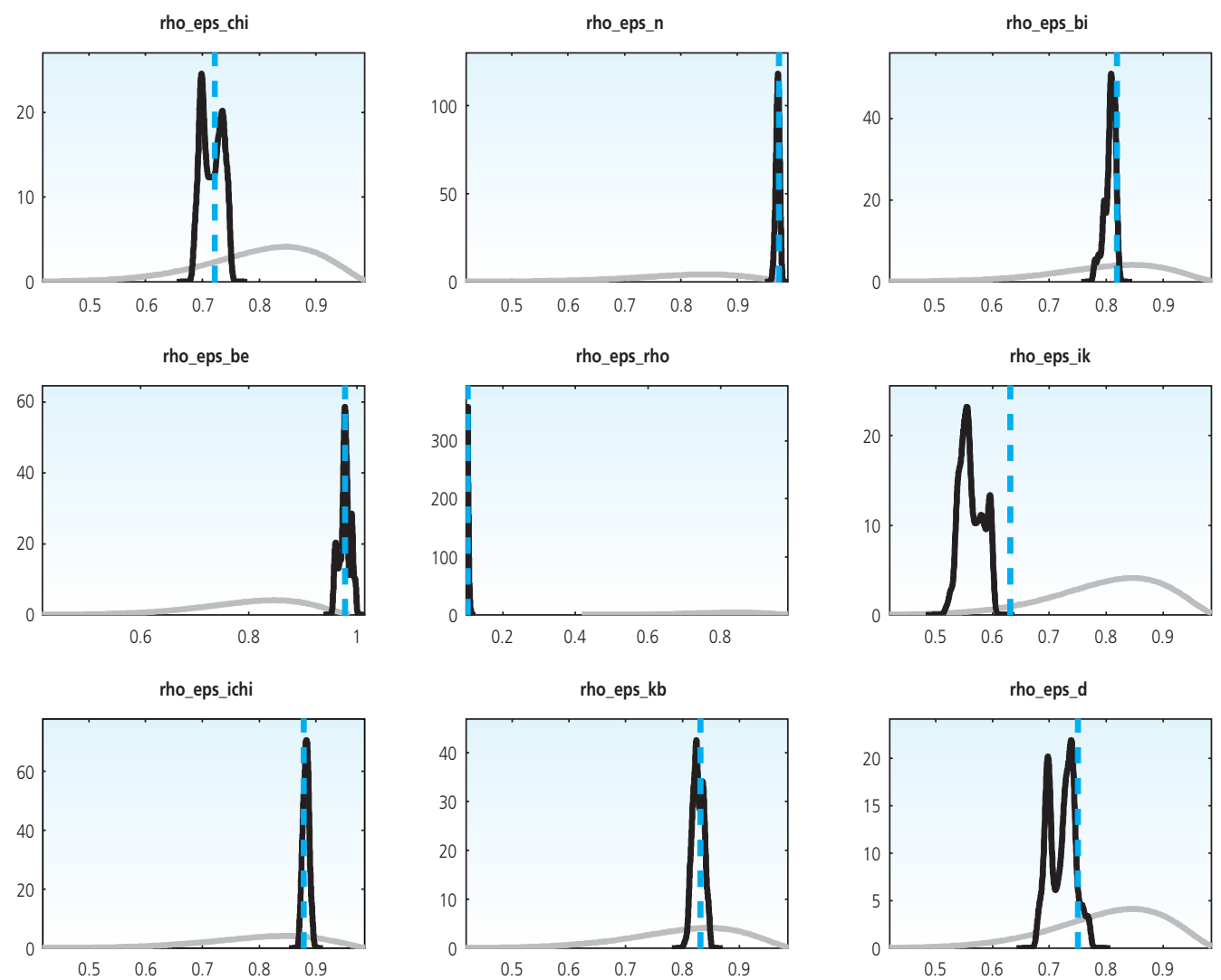
rho $\mathrm{m} i$

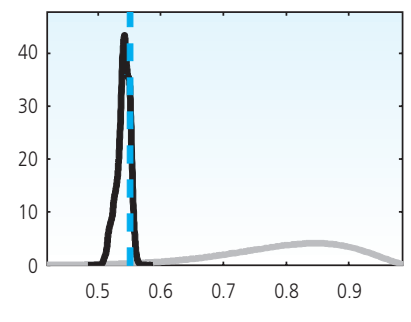

rho_y_st

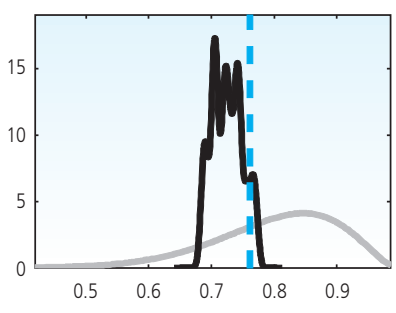

rho a

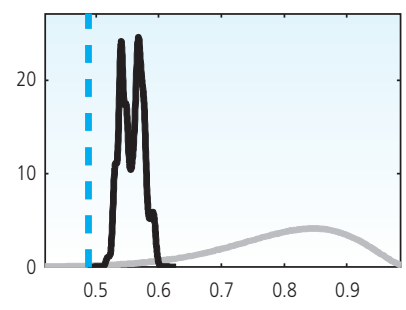

rho_bg

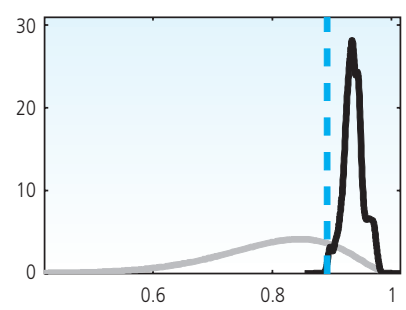

rho_p_f_st

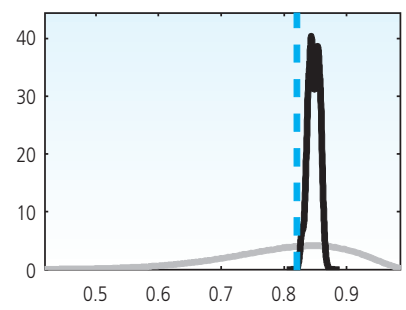

rho_m_e

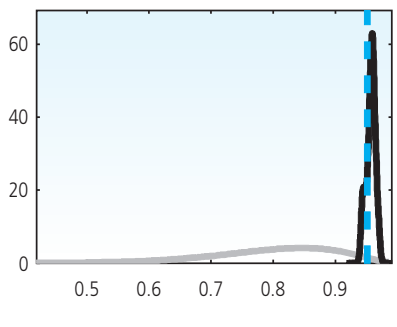

rho_p_st

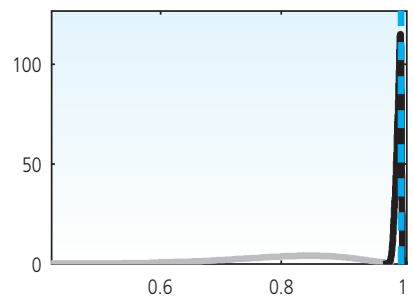

rho nu b

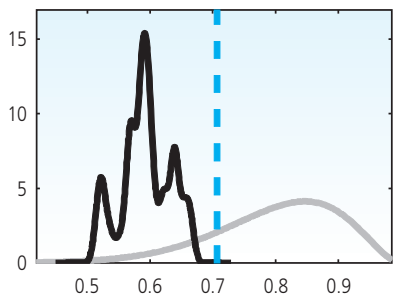

rho_g

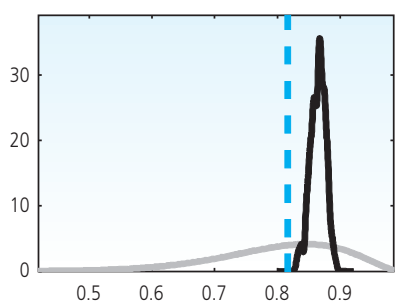

rho_r_bst

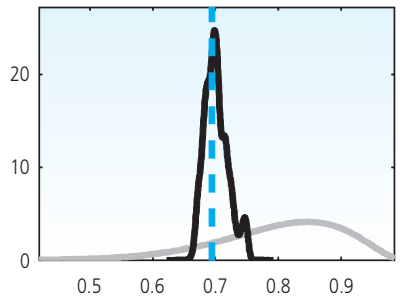

rho_pi_tar

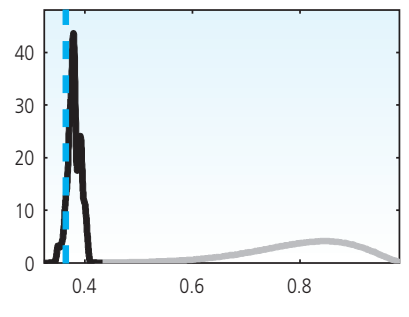

rho bst

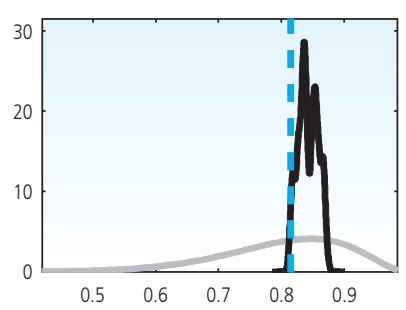

rho_p_hx_st

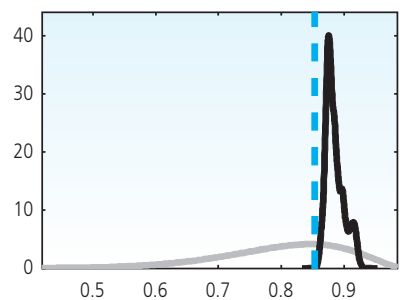


halaman ini sengaja dikosongkan 